\title{
Luz, leis e livre-concorrência: conflitos em torno das concessões de energia elétrica na cidade de São Paulo no início do século XX
}

Alexandre Macchione SAES ${ }^{\bullet}$

Resumo: $O$ artigo discute o processo de introdução da energia elétrica na cidade de São Paulo no início do século XX. A Proclamação da República marcou o início da modernização das empresas de serviços urbanos, com a introdução da eletricidade. Foi neste contexto que dois grupos iniciaram uma intensa batalha no setor elétrico paulista: o grupo nacional da Companhia Brasileira de Energia Elétrica (CBEE) - conhecido também como Docas de Santos - e o canadense Light. A falta de uma legislação federal para o setor de energia elétrica legou às Câmaras Municipais o poder concedente para os serviços de eletricidade, garantindo que as relações políticas entre vereadores e empresários tivessem decisivo papel na instalação de tais serviços. Assim, o artigo descreve o processo de introdução da eletricidade em São Paulo mediante os debates sobre a regulamentação dos serviços públicos, desvendando os critérios políticos ou ideológicos que levaram a conformação de tais leis.

Palavras-chave: Energia elétrica; São Paulo; Light; Docas de Santos.

A década de 1890 marcou o início de um período de concentração e modernização dos serviços públicos no Brasil e, em especial, aqueles relacionados à introdução da energia elétrica no processo de urbanização das principais cidades

- Professor Doutor - Departamento de Ciência e Economia Universidade Federal de Alfenas - UNIFAL - Campus Varginha 37062-440 - Varginha - MG - Brasil. E-mail: alexandre.saes@hotmail.com

HISTÓRIA, São Paulo, 28 (2): 2009 
brasileiras. A cidade de São Paulo, como uma das mais populosas capitais do país e centro comercial e econômico, não poderia deixar de assimilar tais transformações, incorporando as inovações com os serviços de eletricidade para bondes e iluminação pública e particular, além da energia elétrica para fins industriais. Como o uso da energia elétrica exigia das empresas prestadoras de serviços públicos maiores investimentos, a transição para o século XX seria o período em que as tradicionais empresas locais tenderiam a passar por um processo intensivo de unificação, ou mesmo fechamento, cenário este que culminaria com a formação de grandes empresas, como a Companhia Brasileira de Energia Elétrica e o grupo canadense Light.

Mesmo com experiências durante a década de 1880, os serviços de energia elétrica tornar-se-iam uma realidade para os habitantes das mais modernas cidades brasileiras durante os primeiros anos do século XX. Sendo uma realidade extremamente embrionária para o período, a legislação sobre os serviços de energia elétrica era tão rudimentar que poderia ser considerada como inexistente. A única exceção foi a promulgação do Decreto $\mathrm{n}^{\circ} 5.407$ de dezembro de 1904 pelo presidente Rodrigues Alves, que definia linhas gerais: como 90 anos de prazo máximo de concessão, a reversão sem indenização do patrimônio para a União e revisão tarifária a cada cinco anos. No mais, seguindo os preceitos liberais da constituição de 1891, defendia-se a idéia da livre-iniciativa, e, consecutivamente, da proibição de privilégios, e os preceitos federativos da mesma constituição, que legava aos municípios a responsabilidade sobre os contratos e fiscalização dos serviços. Logo, eram os municípios os verdadeiros órgãos concedentes dos serviços de energia elétrica, e a relação entre poder local (prefeitos e vereadores) e empresários tornou-se a base para a definição das concessões de serviços elétricos. Assim, esse artigo se propõe a descrever o processo de introdução da energia elétrica na cidade de São Paulo por meio dos debates em torno da regulamentação dos serviços públicos, desvendando os critérios políticos ou ideológicos que levaram a conformação das 
LUZ, LEIS E LIVRE-CONCORRÊNCIA:....

leis paulistas para o setor de eletricidade.

\section{A segunda fundação de São Paulo e o nascimento dos serviços públicos na capital}

Em meados do século XIX, poucos poderiam prenunciar o que se tornaria a cidade de São Paulo algumas décadas mais tarde. Centro comercial e financeiro da cafeicultura paulista, já nos anos de 1870 a cidade vinha incorporando um vigoroso padrão de crescimento econômico, que, alimentado pela circulação do comércio cafeeiro, gerou a expansão de atividades paralelas, como a formação de ferrovias e bancos. $O$ estímulo à urbanização por meio da ampliação da divisão social do trabalho, da transformação de São Paulo em local de residência dos grandes fazendeiros, entre outras cidades do interior paulista, e da própria dinamização da economia, abriu um novo horizonte para investidores paulistas: o setor de serviços públicos. ${ }^{1}$

A cidade de São Paulo, no último quartel do século XIX, ainda não tinha o mesmo vigor do mercado carioca, nem mesmo a tradição da elite soteropolitana, contudo vinha demonstrando um grande potencial na condução das transformações urbanas. Tanto que, para o historiador Eurípides Simões de Paula (1958), esse seria o período da "segunda fundação de São Paulo". Grandes grupos econômicos e empresários nacionais e internacionais, percorrendo os atalhos para alcançar as elevadas e rentáveis taxas de lucros que a economia proporcionava, passaram a investir nos mais diferentes negócios na região. A companhia ferroviária inglesa, San Paulo Railway, os bancos, English Bank e London \& Brazilian Bank, as diversas casas comerciais de café, os variados negócios do grande capital cafeeiro, eram todas diferentes dimensões de um mesmo processo de expansão econômica. É neste cenário promissor que, de um lado, a companhia canadense Light escolheria o mercado paulista e o setor de serviços públicos como o 
empreendimento inicial do grupo no país, ao passo que, de outro lado, os cariocas Candido Gaffrée e Eduardo Guinle, que já haviam plenamente se estabelecido na cidade de Santos, com a concessão do Porto de Santos, pretendiam conquistar novas atividades. Se, nos primeiros anos do século XX, o objetivo dos dois grupos era, acima de tudo, garantir o controle do mercado do Distrito Federal, não passava despercebido por nenhuma das empresas a relevância do mercado de São Paulo. Por isso que, mesmo com um volume significativo de investimentos tanto da Light como da Guinle \& Co. direcionado para a construção da infra-estrutura elétrica no Rio de Janeiro entre os anos de 1905 e 1907, importantes embates na divisão do mercado paulista aconteceram concomitantes àqueles do Distrito Federal. ${ }^{2}$

Assim, a disputa entre a Light e o grupo Guinle (reconhecido em São Paulo por sua "outra identidade" empresarial Docas de Santos) ${ }^{3}$ refletiria a questão da modernização da cidade de São Paulo. A energia elétrica, como um dos principais meios para a realização do processo de urbanização, tornou-se uma infra-estrutura disputada na cidade em que os capitais nacional e estrangeiro duelariam para garantir parte do mercado paulista. Enquanto a São Paulo Light promovia sua propaganda exaltando o desenvolvimento e as novas tecnologias trazidas do estrangeiro, a Docas de Santos tentava criar um sentimento nacionalista de defesa das empresas brasileiras, estratégia também utilizada no Rio de Janeiro com a aliança com políticos nacionalistas. Para tanto, a campanha da empresa nacional apresentava preços para as tarifas da energia elétrica bem abaixo daqueles de sua concorrente, acusando a São Paulo Light de imperialista e exploradora da sociedade paulistana. Por sua vez, empresários canadenses responderiam às acusações acusando Candido Gaffrée e Eduardo Guinle de hipócritas, no sentido em que eram os custos com os serviços portuários atendidos pela companhia Docas de Santos que penalizavam a população do estado. Nascia, então, nos jornais paulistas, uma disputa mitológica: o "polvo canadense" versus o "minotauro de Santos". 
Mas, antes mesmo do início do duelo de titãs pelo mercado paulista, a chegada da Light em São Paulo já havia causado uma série de agitações na reorganização do setor de serviços públicos. Originadas na década de 1870, a cidade de São Paulo já era atendida por uma série de empresas de serviços públicos. A única estrangeira era a The São Paulo Gás Co. Ltd, fundada em Londres em 1869 e com a autorização de funcionamento concedida em 28 de agosto de 1872, cuja concessão assegurava os serviços de iluminação urbana a gás, realizados por meio de lampiões (SILVA, 2006, p.75). No setor de transportes, algumas empresas dividiam as regiões da cidade: a Companhias de Carris de Ferro de São Paulo, formada, inicialmente, por Manuel Lemgruber e Temístoles Petrochino em 1872, e, absorvendo membros do grande capital cafeeiro na década de 1880, como Francisco de Paula Mayrink, Antônio da Silva Prado e Antônio Paula Ramos, atendia as regióes centrais da cidade. Com o passar do tempo, novos acionistas, de origem do capital urbano e ligados ao comércio e ao setor financeiro, como Antonio Proost Rodovalho, Joaquim Pinto do Carmo Cintra, Ismael Dias da Silva e Joaquim Franco de Lacerda passaram também a compor a lista dos grandes acionistas, de maneira que, em fins da década de 1880, a empresa de bondes já tinha uma diretoria praticamente igual a da importante empresa nacional, Companhia Paulista de Estradas de Ferro. E ainda na década de 1880, duas outras companhias de bondes passariam a percorrer as zonas mais distantes da cidade: a Companhia de Carris de Ferro de São Paulo a Santo Amaro e a Companhia de Carris de Ferro de Santana, formadas, não diretamente, por meio do capital cafeeiro. Dentre as empresas de serviços urbanos formadas na década de 1880 ainda existia a Companhia Cantareira de Esgotos, fundada por Clemente Falcão Sousa Filho, Rafael Pais de Barros e Antônio Proost Rodovalho, que passaria para as mãos do Estado de São Paulo na década seguinte. E, finalmente, ainda nesse período, a primeira proposta de distribuição de energia elétrica para São Paulo foi realizada pela Empresa Paulista de Eletricidade - de Marques, Moutte \& Companhia - 
para servir a estação central, mas que não redundou em sucesso (SAES, 1986, p.145-7).

A década seguinte marcaria o início das transformações, com a tendência a concentração das empresas de serviços urbanos, que culminaria com a vinda da Light para São Paulo na transição para o século XX. Em 1893 ocorreu o início da fusão das companhias de carris urbanos em torno da Companhia Viação Paulista. Em 1897 essa fusão foi ainda mais ampliada, com a afluência das concessões de São Paulo e Santos, reunindo as seguintes companhias: Companhia de Carris de Ferro de São Paulo, Companhia de Transporte Paulista, Companhia FerroCarril de São Paulo, Companhia City de Santos, Companhia São Vicente, Empresa Vila Matias e Empresa Santista. Entre os principais diretores eram listados: Francisco de Paula Mayrink e João Pinto Ferreira Leite. Anos mais tarde, a prefeitura de São Paulo promulgou a Lei Municipal $n^{\circ} 400$, de 11 de maio de 1899, determinando a "unificação dos contratos" da Companhia Viação Urbana, em que garantia mais quarenta anos de privilégio para as regiões já atendidas pela empresa, mas exigiase em troca a substituição gradual dos antigos bondes movidos por meio de animais por bondes elétricos.

Em 1892, foi fundada a Companhia Água e Luz de São Paulo, que, assumindo os projeto do grupo Marques, Moutte \& Comp., tinha o objetivo de fornecer os serviços de eletricidade particular e industrial, água e saneamento. Contudo, os privilégios dos serviços de iluminação públicos a gás ficaram mantidos pela São Paulo Gás Co. por meio da renovação, em 1897, por mais trinta anos, do contrato da empresa com o governo do Estado. Existiam já certas ressalvas ao serviço prestado pela companhia inglesa, mas, diante da falta de concorrentes, a renovação do contrato foi inevitável. Todavia, ao mesmo tempo em que o poder público renovou o contrato com a São Paulo Gás Co., por meio da lei $\mathrm{n}^{\circ} 440$, abriu-se uma cláusula nova no contrato, permitindo a implementação da iluminação por outras empresas mediante matrizes diversas a do gás (SILVA, 2006, p.76). Isto é, o contrato permitia que a empresa fornecesse gás para fins domésticos e industriais, contudo não impedia que 
LUZ, LEIS E LIVRE-CONCORRÊNCIA:...

outras empresas empregassem qualquer outro processo de iluminação nas áreas não atendidas pela companhia, nem que, nas áreas atendidas, fosse produzida, distribuída e vendida eletricidade sem utilização do gás (SOUZA, 1982).

Foi nesse contexto de ampliação da gama de serviços urbanos disponibilizados para a capital e de concentração do número de empresas, que a São Paulo Light foi constituída. O governo federal recebeu a Light com significativo apreço. $O$ projeto de recuperação da economia implementado por Manoel Ferraz de Campos Sales previa a retomada de fluxos de investimento estrangeiro para o país e, assim, o interesse da Light pela capital paulista vinha em boa hora. Em 17 de julho de 1899, por meio do decreto $\mathrm{n}^{\circ} 3.349$, o Ministro da Indústria, Viação e Obras Públicas, Severino Vieira, e o presidente da república, Campos Sales, assinavam a autorização de funcionamento da empresa canadense no país. Para tanto, a empresa deveria se submeter às leis nacionais e apresentar um diretor que residisse no Brasil. $\mathrm{E}$, com a autorização, a companhia receberia alguns direitos, como: do estado de São Paulo, a autorização para desapropriação de terrenos para construção de hidroelétricas, por meio da Lei $n^{\circ} 781$ de 12 de setembro de 1899, e a utilização da cachoeira no Rio Tietê. Em 1904, por meio da Lei no 1.316 de 31 de dezembro, a São Paulo Light recebia do governo federal a isenção de direitos aduaneiros, de desapropriação de terrenos e benfeitorias e providências necessárias às instalações e à execução do serviço público (MENDES, POLETI e SOARES, 1995).

Quatro dias após a permissão do governo federal para entrada da São Paulo Light no mercado brasileiro, em 21 de julho de 1899, a prefeitura paulista promulgava a Lei $\mathrm{n}^{\circ} 407$, para regular os serviços de força e luz da capital do estado. O decreto assinado pelo Prefeito Antonio Prado determinava que toda e qualquer concessão de serviço "de distribuição de força e luz elétricas" dependeria da aprovação e autorização do prefeito. Além de uma longa descrição das quatro zonas de distribuição de força e luz elétrica da cidade e dos materiais e equipamentos que deveriam ser usados pelas companhias, o documento previa 
prazo de no máximo vinte anos de concessão, e que era reservado ao prefeito "o direito absoluto de conceder outras autorizações do mesmo gênero, dentro da mesma zona, com exclusão dos lugares ocupados pelas canalizações já estabelecidas". ${ }^{4}$ A legislação também previa punições para as empresas que não cumprissem os prazos e a qualidade do serviço, as quais, no limite, chegavam a anulação do contrato (artigo 18).

Com as concessões de Gualco e Souza em mãos, em fins de 1899, foi firmado o contrato de concessão entre a companhia canadense Light e a cidade de São Paulo, em que a companhia aceitava os termos do decreto emitido pelo prefeito Antonio da Silva Prado. O contrato de concessão, por sua vez, reafirmava os objetivos da empresa canadense: "A concessão para a construção, uso e gozo de linhas para a produção e distribuição de eletricidade para a iluminação, força motora e outros misteres da indústria e comércio". (SOUZA, 1982, p.29). Tal permissão autorizava a Light a produzir e distribuir energia elétrica em São Paulo, além de permitir a construção de linhas de bondes e de assentar as linhas de transmissão da usina a ser construída no município de Parnaíba. Apesar da abrangência da concessão, a São Paulo Light apenas iniciava sua empreitada para a conquista do mercado paulista, já que este mercado era dominado por outras empresas.

No que diz respeito ao serviço de transportes urbanos, a São Paulo Light temia que a unificação dos contratos da Viação Urbana tivesse garantido grandes poderes à empresa local. Por isso mesmo, no período da unificação dos contratos, a Light, por meio de Gualco e Souza, protestou os termos do contrato, questionando que o monopólio poderia barrar o desenvolvimento que a cidade vinha empreendendo. Nesse sentido, a Câmara Municipal, mesmo mantendo as garantias para a Viação Urbana, emitiu, juntamente com a decisão, a seguinte notificação: "não se deve pensar a unificação como impedimento de estabelecimento de outras empresas de transporte do mesmo gênero; a junção só diz respeito às linhas já assentadas". ${ }^{5} \mathrm{E}$ justamente por meio dessa brecha a São Paulo Light tentaria 
adentrar o mercado paulista de transportes urbanos, ainda mais considerando que a concessão transmitida de Francisco Gualco e Antônio Sousa para a companhia Light, referente a Lei Municipal $\mathrm{n}^{\circ}$ 304, já previa o estabelecimento de linhas de bondes elétricos. Então, antes mesmo do final de 1899, a companhia canadense iniciou suas obras para assentar os trilhos conforme as estipulações existentes na lei $\mathrm{n}^{\circ} 407$.

Mas esse avanço da Light no mercado paulista era considerado irregular para os diretores da Viação Paulista. Conforme recursos apresentados à Câmara Municipal, acreditavam os diretores que as linhas da concorrente seguiam percursos paralelos ao da Viação, de maneira a não respeitar os "lugares ocupados". Durante meses, Carlos de Campos, advogado representante da Light, e Manoel Pedro Villaboim, advogado representante de Viação Paulista se enfrentaram em longos embates na Câmara Municipal, que ora autorizava a Light a continuar suas obras, ora determinava o embargo das obras da companhia estrangeira. $\mathrm{Na}$ disputa jurídica, a São Paulo proclamava o discurso da livre-concorrência, caminho que permitiria a companhia suplantar os serviços de sua concorrente. Os jornais também tomavam parte do debate sobre a livre-concorrência, criticando o controle da prefeitura sobre as concessões de serviços públicos:

Admitida a livre-concorrência, é obvio que ela só poderia ser praticável mediante um certo número de prescrições no tocante à serventia das ruas e praças e à municipalidade competia estabelecê-las e sujeitar a elas todos quantos pretendessem fazer instalações. Mas a isso, exclusivamente a isso, devia limitar-se a ação municipal. Contudo, assim não sucede. Pela lei à que estamos nos referindo (lei $\mathrm{n}^{\circ} 407$ de 6 de julho de 1899), ninguém pode fazer instalações de força e luz elétricas sem sujeitar-se a um prazo, que não pode exceder de 20 anos, sem estabelecer certos e determinados preços, cujos máximos são, de antemão, determinados pela mesma lei. Eis aí como a livreconcorrência fica burlada e como a Câmara Municipal exorbita das suas atribuições, querendo imiscuir-se na vida íntima das 
empresas, querendo tolher o livre comércio e a expansão de uma indústria lícita, conhecida e explorada em todo o mundo. ${ }^{6}$

A solução encontrada por Alexander Mackenzie foi pressionar financeiramente a Companhia Viação Paulista, que já se encontrava bastante endividada. Depois de longos trâmites com os avalistas da companhia nacional, a São Paulo Light conseguiu levá-la a liquidação, absorvendo concessões e equipamentos por meio de leilão realizado em 21 de maio de 1901. A Câmara Municipal, por meio da lei $n^{\circ} 528,17$ de julho de 1901, unificava agora os direitos da Light no serviço de transporte, pois, ao ter absorvido também as outras duas empresas de São Paulo, assumia, então, o monopólio do serviço de bondes na cidade. ${ }^{7}$

Já a absorção da companhia de Água e Luz do Estado de São Paulo não seria tão atribulada. A empresa que servia a cidade com energia elétrica do escurecer até a meia-noite em algumas poucas residências nas zonas centrais dependia de uma pequena usina a vapor localizada na rua Araújo. No início de 1900, a São Paulo Light já havia iniciado as obras da usina de Parnaíba e logo tornaria a disputa pelo mercado extremamente desigual com a Água e Luz. Conforme o relatório da própria companhia nacional:

No mês de setembro deste ano a Companhia Light and Power iniciou a distribuição nesta cidade de corrente elétrica produzida em sua usina em Paraíba, estabelecendo de conformidade com anúncios anteriormente feitos, o preço de $4 \$ 000$ por cada lâmpada por mês, sendo este preço mais ou menos a metade do que esta companhia havia até então cobrado. Prevendo que a concorrência da Light \& Power Company resultaria para nós em uma perda total de consumidores, se os nossos preços não fossem reduzidos ao mesmo algarismo e sendo impossível fazer essa redução sem uma correspondente redução nas despesas de custeio, entramos em acordo com a Light \& Power para comprarlhes corrente para os nossos consumidores por um preço muito abaixo do custo de produção em nossa usina. (...) Não obstante havermos reduzido nossos preços igualando-os aos da Light \& 
LUZ, LEIS E LIVRE-CONCORRÊNCIA:...

Power, o número de nossos consumidores diminuiu consideravelmente. (...) Em nossa opinião é impossível a companhia continuar a funcionar e, portanto, recomendamos a sua liquidação amigável, de acordo com a lei. ${ }^{8}$

A "liquidação amigável" daria plenos poderes a Light no que concerne aos serviços de energia elétrica. Com a compra da maioria das ações da companhia Água e Luz, a Light, já nos primeiros anos do século $\mathrm{XX}$, montaria uma diretoria própria na administração da empresa, com o advogado Carlos de Campos, Fernando de Albuquerque e Octávio Pacheco e Silva, até a consumação do processo de incorporação da empresa para os balanços da Light em dezembro de 1908.

Assim, a iluminação elétrica, serviço rapidamente controlado pela São Paulo Light na capital, em pouco tempo passou a ser considerado como uma necessidade básica para a sociedade paulistana. A Light procurou servir inicialmente os bairros centrais e, portanto, mais populosos da cidade. Afinal, para a realização do serviço de iluminação era necessária a montagem de todo um custoso aparato que envolvia desde a usina geradora, os fios de distribuição, até os postes de iluminação. Enquanto a Light avançava pelos bairros centrais, a municipalidade mantinha o privilégio da concessão do serviço de iluminação pública para a São Paulo Gás Co. nos lugares já ocupados pela empresa inglesa. A disputa entre as duas empresas se daria no campo da iluminação particular, em que a Light, segundo a renovação do contrato da companhia inglesa de 1897, poderia oferecer serviços por meio da iluminação elétrica para as residências enquanto a São Paulo Gás Co. fornecia iluminação por meio dos lampiões de gás. A disputa entre as empresas, e suas tecnologias, seria acirrada até o início da década de 1910, quando inovações nos equipamentos de iluminação elétrica, com a substituição das lâmpadas de filamento de carvão, por aquelas de filamento de tungstênio, ${ }^{9}$ tornariam a concorrência com a eletricidade quase impossível. ${ }^{10}$

A São Paulo Gás Co., a partir de então, preservou sua concessão no campo da iluminação pública por meio do gás nas 
áreas já ocupadas, sem promover nenhuma expansão, resultado da competição com a iluminação elétrica e do encarecimento da matéria-prima, o carvão, que era importado. As dificuldades financeiras eram candentes, e era somente o monopólio do fornecimento de gás para fins domésticos que garantia a sobrevivência da empresa. Mesmo diante dos maus resultados financeiros, em 1912 a companhia Light realizou uma custosa operação financeira, de $£ 650.115$, para conquistar o controle acionário da empresa inglesa, com o intuito de blindar as possibilidades de concorrentes no mercado de São Paulo - no caso, a CBEE (SILVA, 2006, p.79). Com autonomia jurídica, a São Paulo Gás Co. passou a investir no uso doméstico do gás com apoio de campanhas publicitárias, enquanto a Light ampliou os serviços de energia elétrica.

Esse cenário de expansão da energia elétrica pelos bairros da cidade fazia com que as comunidades das localidades ainda não atendidas começassem a reivindicar tal inovação. Tais bairros não haviam sido incluídos nas zonas de atendimento da São Paulo Gás Co. e, por isso, poderiam ser atendidos por meio de luz elétrica pela Light. Enquanto isso, viviam às escuras com os lampiões de querosene. Assim, nos jornais da época, eram recorrentes as manifestações dessas comunidades "distantes" exigindo do governo as instalações dos equipamentos mais "modernos", isto é, a luz elétrica. Como por exemplo, na Penha:

A Penha, como se sabe, é iluminada a querosene, iluminada? Não; a Penha, de há muito, permanece em trevas... com sua iluminação a querosene. Essa iluminação é feita por conta da municipalidade, quando tal serviço compete ao governo, desde que este começou a arrebatar ali o imposto predial.

Aproximando-se a tradicional festa da padroeira daquela freguesia, grande número de moradores delegou poderes ao Sr. Aníbal Machado para obter do governo a iluminação elétrica da localidade, em substituição à atual... ausência de iluminação (...) Atendendo a seu pedido de informações, o Sr. Superintendente da "Light and Power" dirigiu ontem ao Sr. Aníbal Machado uma carta que consta o seguinte tópico: "Esta Companhia se prontifica a fazer sem demora a instalação referida (iluminação 
LUZ, LEIS E LIVRE-CONCORRÊNCIA:...

pública), com um caráter provisório. (...) Recebendo do estrangeiro o material necessário, a instalação será então estabelecida de modo definitivo, sem despesas extraordinárias". ${ }^{11}$

Até a aquisição acionária da companhia inglesa, a Light tinha grande interesse em assumir os serviços desses bairros mais distantes, evitando assim que a São Paulo Gás Co. assentasse seus materiais, transformando tais localidades em "lugares ocupados". Assim, na medida do possível, as inovações da Light foram tanto transformadoras como rápidas. A introdução dos novos bondes e da iluminação elétrica impulsionou a defesa da modernização por parte da população paulistana. Os relatos nos jornais nos primeiros anos do século XX exaltavam as inovações e a conseqüente mudança de hábito da população: "Iluminação elétrica: Era belíssimo ontem, à noite, o aspecto da rua Barão de Itapetininga, fartamente iluminada, por lâmpadas de arco, suspensa sobre cada poste da Light". ${ }^{12}$ Através da nova e mais eficiente iluminação era possível que as pessoas tivessem uma vida noturna mais segura e, por isso mesmo, que os passeios durante a noite, mesmo que só para olhar a nova iluminação, se tornassem freqüentes. Em 1907, na comemoração do 20 de setembro, os jornais esperavam $20 \mathrm{mil}$ pessoas para festa que incluía piquenique, música e baile. $\mathrm{O}$ destaque da notícia do jornal era a nova iluminação noturna. ${ }^{13}$

Enquanto a Light foi crescendo dentro da cidade de São Paulo, no restante do estado algumas pequenas empresas municipais já haviam iniciado a geração da energia elétrica para reduzidas localidades. No interior, as empresas municipais de iluminação e geração de energia passaram também a promover obras para substituir a iluminação a querosene pela elétrica, via usinas a vapor ou pequenas hidrelétricas. As cidades que demandavam maiores quantidades de energia, pelo tamanho da população e pela existência de fábricas, acabavam por buscar essa nova forma de geração de energia. Ao mesmo tempo, diante das facilidades que a energia elétrica prestava à indústria, estas ampliaram a necessidade de sua expansão, 
levando as empresas a criar suas próprias fontes de energia por meio de pequenas usinas geradoras. ${ }^{14}$ Podiam assim, evitar o gasto com as empresas fornecedoras e ter autonomia no crescimento. A Light, percebendo a expansão da produção de energia elétrica particular, começou uma campanha para evitar que essa distribuição de energia fosse feita por outras empresas, ou mesmo, indústrias independentes. A reivindicação da Light estava no sentido de promover uma unificação dos contratos sobre a distribuição da energia elétrica na cidade de São Paulo. Afinal a única lei sobre as concessões dos serviços de eletricidade era a relativa à concessão feita a empresa canadense em 1899, que deixava inúmeros pontos sem esclarecimentos. Portanto, era necessário especificar alguns termos e procurar definir algumas cláusulas, tais como se o serviço dentro da cidade de São Paulo deveria ser oferecido por uma única empresa ou por mais de uma, e quais seriam as taxas cobradas para consumidores urbanos, industriais e serviços públicos.

Logo, se a livre-concorrência havia beneficiado a Light tanto no controle dos serviços de transporte como de eletricidade, não levaria muito tempo para que a empresa mudasse seu discurso. Na luta por seus direitos, uma das principais empresas a comandar a independência das indústrias frente à produção de energia elétrica da Light foi a Klabin Companhia de Fabricação de Papel. Se, de um lado, a entrada da Light no mercado auxiliava a formação de novas e menores empresas, que não precisariam dispor de vultuosos recursos para instalar equipamentos motrizes, de outro lado, para aquelas empresas que já haviam conquistado as licenças, ou mesmo já disponibilizado sua própria geração de energia, recair sobre o monopólio da Light seria perder seus investimentos iniciais. Vale ressaltar que, no ano de 1912, percebendo a possibilidade de uma reformulação das leis sobre o uso da eletricidade, com a unificação dos contratos da São Paulo Light ${ }^{15}$ e a conseqüente monopolização do serviço de geração e distribuição de energia elétrica, a Klabin emitiu à Câmara Municipal o seguinte ofício: 
Os suplicantes já obtiveram desta Municipalidade autorização para trazerem a força de uma cachoeira de sua propriedade, afim de utilizá-la nas indústrias que já têm montadas e em outras que vierem a montar. A concessão foi outorgada a si e ao Sr. Abílio Soares, por lei municipal $n^{\circ} 1177$ de 23 de dezembro de 1908 e referia-se a uma queda de água do rio Cotia. (...) Hoje eles querem apenas pedir à Câmara Municipal que, tendo em vista as razões expostas, não deixe desamparados os direitos dos munícipes e, especialmente, dos industriais, para que São Paulo possa caminhar na senda do progresso sem os formidáveis entraves que um monopólio pode criar. ${ }^{16}$

Ao mesmo tempo em que as empresas começavam a questionar os contratos pretendidos pela Light, os empresários Cândido Gaffrée e Eduardo Guinle constituíram uma empresa com fins específicos para fornecer energia elétrica para a capital do Estado. No ano de 1909, consolidando o projeto, formavam a empresa Companhia Brasileira de Energia Elétrica, oficialmente criada no dia 27 de maio de 1909, na cidade do Rio de Janeiro, tendo como presidente o Sr. Candido Gaffrée, e como principal acionista Eduardo Guinle. O projeto dos empresários cariocas era pretensioso: queriam fornecer energia para as principais capitais brasileiras, como estava descrito na ata da reunião da assembléia de constituição da empresa, publicada pelo jornal $O$ Estado de São Paulo:

Art. $1^{\circ}$. Sob a denominação de Companhia Brasileira de Energia Elétrica, é formada uma sociedade anônima, tendo por objetivos: a) explorar as seguintes concessões feitas a Guinle \& Comp. e concernentes ao aproveitamento de transmissão e distribuição de energia elétrica. b) (...) exploração das linhas telefônicas na cidade da Bahia. c) explorar os contratos celebrados por Guinle \& Comp, com o ministro da indústria, viação e obras publicas para - suprimento de energia elétrica para os serviços públicos federais no Distrito Federal, (...) e com o Estado do Rio de Janeiro, para o fornecimento de energia para a iluminação publica e particular para o suprimento da cidade de Niterói, (...) Petrópolis, Magé, São Gonçalo (Estado do Rio de Janeiro), 
Salvador da Bahia, Sto. Amaro, S. Felix e Cachoeira (Estado da Bahia), e São Paulo (Estado de São Paulo). ${ }^{17}$

Em São Paulo, especificamente, buscavam aproveitar o excedente de energia produzido na usina de Itatinga, aproveitando o aumento na demanda por energia elétrica na cidade. Itatinga era uma cachoeira que alimentava a usina de energia elétrica do Porto de Santos, que estava desde 1892 sobre concessão da Companhia Docas de Santos, isto é, dos empresários Guinle e Gaffrée, fundadores da Companhia Brasileira de Energia Elétrica. Desta forma, existindo um excedente de energia produzido no porto, os empresários procuraram disponibilizar o serviço de distribuição de energia para as áreas ainda não atendidas com a eletricidade na cidade de São Paulo. ${ }^{18}$

A campanha elaborada por Guinle's \& Co. demonstrava para a população que uma nova empresa poderia trazer benefícios para toda a cidade. Defendiam que, se a Docas de Santos tivesse autorização para fornecer energia para a cidade de São Paulo, a empresa poderia oferecer baixos preços beneficiando especialmente as áreas não atendidas da cidade. Com o desígnio de cooptar a população, os empresários promoveram uma grande propaganda dentro dos meios de comunicação, como no jornal A Gazeta:

Requerimento de Concessão: Conforme publicação em todos os jornais, o Sr. Guinle \& Comp., requerem a dias à prefeitura uma concessão para assentar as linhas de canalização elétrica em São Paulo, com a promessa dourada de fornecerem ao nosso público luz e força elétrica por preços excepcionais, nunca vistos, a alcance das bolsas menos remediadas. ${ }^{19}$

Os conflitos para obtenção da concessão no Distrito Federal estavam se expandindo. Assim, em momento algum o projeto da concorrente Docas de Santos, de trazer a energia elétrica excedente de Santos para a capital, causou espanto para a Light, que já tinha conhecimento de alguns planos da empresa 
LUZ, LEIS E LIVRE-CONCORRÊNCIA:...

desde 1907. Já no relatório anual da Light de 1907, os empresários canadenses radicados no país avisavam aos diretores e acionistas estrangeiros sobre os possíveis embates com o grupo Guinle no mercado paulista:

Durante esse ano o Dr. Souza, nosso engenheiro elétrico, foi encaminhado para realizar uma investigação sobre as instalações que vêm sendo construídas pela Companhia Docas de Santos, próximo à cidade. Guinle \& Co., grupo que está intimamente associado à Companhia Docas, declarou sua intenção de trazer energia elétrica para São Paulo (SP LIGHT, 1907, p.53).

A Light, entretanto, não acreditava que a companhia Docas de Santos teria condições de oferecer energia para São Paulo tão rapidamente. Afinal, como era descrito no relatório anual de 1908, a Light tinha assinado contrato com a prefeitura de São Paulo para o período de mais oito anos de privilégio na distribuição de energia elétrica (SP LIGHT, 1908, p. 99). Mas as vantagens oferecidas pela Companhia Brasileira de Energia Elétrica eram tamanhas que o prefeito, na ocasião Antônio Prado, não deixou de pensar positivamente sobre a entrada de Guinle no setor de serviços da cidade de São Paulo. Medida tomada em 25 de fevereiro de 1909, e publicada dias depois no $O$ Estado de São Paulo, Antônio Prado autorizava a companhia Docas de Santos a distribuir energia elétrica para a capital:

Um telegrama de São Paulo nos trouxe a auspiciosa notícia, que o eminente prefeito da capital, o Sr. Conselheiro Antônio Prado, deu a Guinle \& Comp. a concessão para o fornecimento de energia e luz elétrica. O sistema adaptado da legislação para estes serviços da capital paulista é o da livre-concorrência. ${ }^{20}$

A idéia inicial que estava sendo apresentada seria a de Guinle disponibilizar seus serviços para aquelas áreas em que a Light ainda não havia conseguido avançar até determinada data. Voltava-se aos argumentos previstos na lei $\mathrm{n}^{\circ} 407$, em que o prefeito tinha plenos poderes para conceder novas autorizações, 
inclusive dentro das mesmas zonas de atuação, mas devendo respeitar "os lugares ocupados pelas canalizações já estabelecidas". Em suma, a prefeitura paulista reafirmava o discurso da livre-concorrência. Para tanto, já no ano de 1908, foi iniciada a construção da linha que levaria energia de Santos para São Paulo. Deste momento em diante, uma grande luta comercial e política foi travada pelas duas empresas para a tentativa de consolidação de um novo mercado, por parte da Docas, enquanto a Light buscava manter o monopólio sobre a distribuição e geração de energia para a capital paulista. $O$ conflito entre as empresas, entre o capital nacional e o capital estrangeiro, entre o polvo canadense e o minotauro de Santos, invadiu a Câmara e extravasou pelos meios de comunicação, levando a população às ruas!

\section{O polvo versus o Minotauro: conflitos em torno das concessões de energia elétrica}

Reproduzindo os conflitos em torno das concessões da energia elétrica no Distrito Federal, em São Paulo os primeiros embates entre as empresas São Paulo Light e Docas de Santos e a municipalidade ocorreriam com relação à temática da livreconcorrência. A Light que, enquanto buscava consolidar seu controle sobre os serviços públicos, como diante a concorrência com a Viação Paulista, era defensora da livre-concorrência, ao conquistar o mercado paulista e o carioca, iniciou uma astuciosa campanha em defesa dos monopólios naturais. Considerando o setor de energia elétrica como um setor que envolvia, por parte dos fornecedores, uma série de altos investimentos iniciais, como a construção de usinas de geração de energia envolvendo as mais modernas tecnologias e os elevados capitais para o período -, a instalação de aparelhos para a transmissão e distribuição da energia, e ainda, uma classe trabalhadora relativamente qualificada para a montagem e a manutenção dos equipamentos, a Light passou a defender a idéia de que os 
LUZ, LEIS E LIVRE-CONCORRÊNCIA:...

serviços públicos deveriam ser garantidos por meio de privilégios.

Por outro lado, novamente com base no caráter liberal de "livre-iniciativa" da constituição brasileira (artigo 72, parágrafo 24), caráter este confirmado em São Paulo pela municipalidade (lei $\mathrm{n}^{\circ} 407$ ), os diretores de Guinle \& Co. iniciaram uma outra campanha para conquistar o mercado de energia elétrica, agora em São Paulo (GUINLE \& CO, 1911, p. 5). Afirmavam que, com a promoção da livre-concorrência, haveria a tendência de uma luta por preços e uma conseqüente redução destes. Eduardo Guinle enfatizava que sua empresa estava oferecendo o serviço de energia elétrica por preço até oito vezes mais barato do que aqueles cobrados pela concorrente, ${ }^{21}$ o que forçaria a São Paulo Light reduzir suas tarifas. Previam assim que a aprovação no negócio resultaria não só na redução dos preços, benéfico para todos consumidores, mas também em uma mais rápida disseminação do serviço pela cidade. Para pressionar a sociedade e políticos, a companhia Docas de Santos iniciou um ofensivo ataque dentro dos meios de comunicação e dos órgãos políticos. No artigo publicado em A Notícia, com o título "A Light e Docas", era destacado as vantagens que um sistema de livreconcorrência traria para a população de São Paulo:

O telegrama enviado ontem pelo Sr. Alexander Mackenzie, presidente da Cia. Light and Power, ao Sr. Presidente do Estado, sobre o fornecimento de energia elétrica às repartições subordinadas à Secretaria da Agricultura provoca algumas considerações de parte dos que, como nós, julgamos grande benefício para a população desta capital a concorrência de mais uma empresa exploradora de energia elétrica (...).

Tendo sido publicado na Imprensa o Edital chamando concorrentes para o fornecimento de energia elétrica nas diversas repartições da Secretaria de Agricultura, a 31 de agosto último, apresentaram-se apenas os Sr. Guinle \& Comp. tendo a Light \& Power deixado de apresentar proposta embora já fosse fornecedora por preço muito mais elevado do que aqueles do concorrente. 
O jornal relatava a existência de um edital para a apresentação de propostas para o fornecimento de energia na cidade de São Paulo em que a Light não havia comparecido. Na capital era o governo estadual, por meio de acordo com a municipalidade, o órgão responsável pela contratação e pagamento pelos serviços de iluminação pública. Assim, nos anos iniciais do século XX, a Secretaria da Agricultura e Obras Públicas lançou alguns editais para a prestação dos serviços de energia elétrica, mas sempre se mantendo bastante conservadora, ao preservar as concessões de iluminação da São Paulo Gás Co. Isso levou o governo a não aceitar grande parte das propostas enviadas pelos proponentes durante toda a década de 1900, considerando que os serviços de iluminação elétrica eram mais custosos do que aqueles servidos por gás. De qualquer maneira, a Light foi paulatinamente assumindo a iluminação pública do subúrbio da cidade, como os bairros da Penha, Lapa, Vila Mariana, Pinheiros e Santana, e, no centro, por meio de promoções para edifícios e ruas especiais, como o Teatro Municipal e as ruas comerciais do "Triângulo", ou para homenagear personagens, como na visita do Presidente da República Afonso Pena em 1908 (SOUZA, 1982, p.136). De outro lado, embasada nos preceitos da livre-concorrência, a Docas de Santos procurava exatamente as brechas do mercado paulista para garantir ao menos pequenas concessões. A Light tentava se defender:

Alega o presidente da poderosa Companhia canadense, Light \& Power, que fez custosas e importantes instalações, por conta exclusiva e sem nenhum auxílio público. Ora, que se saiba, a nossa empresa que se propôs fornecer energia elétrica para essa capital também fez custosas e importantes instalações, por conta exclusiva. O auxílio público que recebemos, teve também a Light, isso é, a isenção de direitos para o material importado.

As taxas pagas pela Light, em virtude de leis e contratos, hão de ser pagas também pelos que pretendem explorar tais serviços e não poderá ficar isenta delas a Companhia Docas de Santos. Porque pensa Alexander Mackenzie que a Docas esta isenta dessas taxas? Só por isso, porque o público terá a lucrar com o 
estabelecimento de mais um fornecedor, fazendo votos pela empresa da Casa Guinle nesta capital, guardadas todas as disposições legais e garantidos todos os direitos adquiridos. Console-se, pois, a Light, porque nem sempre se pode negociar sem concorrentes, impondo o preço, garroteando o povo. ${ }^{22}$

A justificativa que Alexander Mackenzie apresentava era de um alto custo de instalação que deveria ter um prazo de retorno, em outras palavras, o privilégio, até a entrada de novas empresas no mercado. O questionamento no jornal defendia que a companhia Docas de Santos não deixaria de ter tais custos de instalações, e, por isso, as condições seriam absolutamente as mesmas para as duas empresas. Desta forma, na opinião da Docas de Santos, o sistema de livre-concorrência beneficiaria a sociedade.

Em jornal, no ano de 1909, Alexander Mackenzie e Alfredo Maia retomavam a argumentação dos custos de instalação, apresentando para a sociedade quais eram os custos da Light para a organização do projeto de fornecimento de energia elétrica. ${ }^{23}$ Como era relatado, até 1903 , a Light havia despendido 12 mil contos de réis para a construção de sua usina e instalação da fiação de distribuição e para a compra da empresa de Água e Luz por 2:000\$000. De outro lado, a empresa apresentava seus lucros anuais, afirmando que não atingiam mais que $6,5 \%$ do capital empregado ${ }^{24}$ e, consecutivamente, não seria possível continuar investindo se fosse necessário baixar ainda mais as tarifas - que segundo a empresa estavam abaixo do contrato. Conforme argumentavam, a renda líquida de 1907 e 1908, por exemplo, havia sido de $1.434 \$ 099$ e $1.536 \$ 009$ réis, respectivamente, dinheiro insuficiente para consolidar, inclusive, a compra da companhia de Água e Luz. ${ }^{25}$

Por outro lado, a Docas de Santos não estava isenta das taxas de funcionamento e de todos os custos de instalação para geração da eletricidade para a capital - que também seriam despendidos particularmente, sem apoio dos órgãos públicos. $\mathrm{O}$ único apoio do governo era aquele para empresas denominadas de "serviços públicos", isto é, tanto a Light como Guinle \& Co. 
teriam isenção de impostos alfandegários e direito a desapropriação de terrenos para construção de usinas e linhas de transmissão. Ademais todos esses custos, a Docas de Santos oferecia um preço reduzido em comparação com a Light. Foi nesse contexto que a São Paulo Light passou a rebater as críticas da concorrente nos jornais, usando como principais aliados na defesa, os jornais A Gazeta e A Platéia, ambos ligadas aos empresários da Light. ${ }^{26}$ Se de um lado a empresa se valeria da defesa de monopólios naturais para os serviços públicos, a Light também colocaria em dúvida as ações da família Guinle, acreditando que estes não tinham condições de oferecer serviços por aqueles preços, mas apenas queriam colocar a população contra o capital internacional. Nesse sentido, tanto no jornal $A$ Gazeta como na Platéia, alguns artigos utilizavam a sátira e a ironia para reverter os argumentos do grupo nacional Docas de Santos. No artigo "Privilégios ou livre-concorrência? Autoridade insuspeita - nunca se é traído...", o jornal lightiano A Platéia se posicionava:

Bem diz o ditado: "da discussão surge a luz", o que ao caso da Light x Guinle se ajusta como uma luva em mão de moça bonita. Nunca chegamos a compreender como um serviço público indispensável, que depende da ocupação do leito das ruas e do emprego de grandes capitais, pudesse ser entregue aos azares da livre-concorrência, como qualquer pequeno negócio de bugigangas. Pareceu-nos sempre mais conforme a boa razão e conveniente ao interesse público, que fosse esse serviço confiado a uma empresa que o executasse em condições estabelecidas por contratos, com obrigações de todos servir nos termos estipulados. ${ }^{27}$

A crítica da Light estava presa à idéia da anarquia que um estado totalmente liberal poderia trazer para a sociedade. Numa sociedade com a falta de regulação dos serviços públicos, várias empresas poderiam oferecer a energia elétrica e, assim, numa mesma rua poderiam existir fios e postes de diferentes empresas, gerando um caos na prestação de serviços. Portanto, Alexander Mackenzie defendia a manutenção das "condições 
estabelecidas por contratos", de forma que a Light, como detentora da concessão da cidade de São Paulo não fosse ameaçada pela concorrência. No entender do empresário canadense, com o passar do tempo, enquanto o retorno do capital investido estivesse garantido, a Light poderia ampliar os serviços e reduzir o preço de suas tarifas.

$\mathrm{E}$, juridicamente, a Light buscou auxílio no formato dos serviços urbanos norte-americanos, se apoiando na argumentação de doutrinas de advogados dos EUA como Clarke Hare (American Constitutional Law) e John Dillon (Commentaries on the law on the municipal corporations). Aproveitava-se, neste sentido, do conflito que vinha ocorrendo no Distrito Federal, em que os órgãos jurídicos da Rio Light haviam construído uma ampla defesa da idéia de monopólios naturais, com auxílio, inclusive, de Rui Barbosa. Francisco Castro Jr., outro dos advogados da Light, escreveu em 1909 um longo texto considerando que a tendência da prestação de serviços municipais na Grã-Bretanha e EUA era de concessões em regime de monopólio, estrutura que deveria ser estendida para o Brasil. No Brasil, apoiando a Light, a argumentação jurídica norteamericana foi rapidamente incorporada pelo grande intelectual e advogado da Light, Rui Barbosa, que afirmava: "A livre competência entre tantas companhias e pessoas quantas quisessem estender fios para a condução de eletricidade pelas ruas seria impraticável" (CASTRO Jr., 1909, p. 18).

Mas as pressões da Docas de Santos continuavam, de maneira que a Light começou a propor reduções de tarifas, demonstrando que realmente as cobranças poderiam ser abusivas. A Light, então, baixou as taxas de força e luz: de 800 para 500 réis o preço máximo para a luz elétrica do kwh, e de 700 para 300 réis os máximos de força elétrica. ${ }^{28}$ Esse fato levou a Docas de Santos a reforçar uma campanha para mostrar como a Light era uma empresa desleal. Afinal, as reduções da Light, só aconteceram porque a Docas se disponibilizou para fornecer o mesmo serviço por menores preços. Até então, os preços apresentados pela Light eram tidos como mínimos: 
Ao anunciar-se agora que outra firma pedira licença para concorrer com a Light, imediatamente os diretores dela precipitaram-se daqui para São Paulo e ofereceram fazer grandes reduções, contanto que não se desse a concessão. (...) Pelo simples fato de prometer grandes reduções de preço, quando até ai estando sozinho em campo, sempre tinha afirmado que os seus preços já eram mínimos, a Light provava mais uma vez, redundante e pleonasticamente, a sua desonestidade. ${ }^{29}$

Nesse ano de 1909, existia uma boa perspectiva de Guinle vencer a batalha contra a Light. A empresa já afirmava em artigos de jornais a vitória, "é que a concessão agora foi feita pelo Dr. Antônio Prado". ${ }^{30}$ Afinal de contas, como informavam os jornais, os preços da Docas eram realmente muito mais rentáveis: para a força ofereciam o serviço à 70 réis, enquanto a Light estava oferecendo à 300 réis, e para a luz particular ofereciam 200 réis, enquanto a Light distribuía por 500 réis. ${ }^{31}$ Assim, no dia 25 de fevereiro de 1909, o prefeito havia assinado a concessão da distribuição de energia elétrica, aceitando os serviços da Docas de Santos para a capital do estado. A Docas, então, teria quatro meses para apresentar e aprovar as plantas de instalação da rede elétrica. ${ }^{32}$ Desta forma, se Guinle teria que correr para propor um projeto de iluminação da cidade, a Light tinha menos de quatro meses para defender seus interesses, e proibir a entrada da concorrente em seu mercado.

Uma das saídas para a Light procurar contestar a Docas de Santos era questionar a utilização da cachoeira de Itatinga. A justificativa usada pela Light era a de que o uso da cachoeira de Itatinga, nos domínios da Docas de Santos, tinha exclusividade para atender os serviços portuários. ${ }^{33} \mathrm{~A}$ abrangência de tal concessão de utilização dos "rios que os respectivos estudos demonstrassem convenientes" já havia gerado profundas críticas no Senado. Alguns senadores censuravam a aprovação de tais medidas, questionando o poder que os empresários Candido Gaffrée e Eduardo Guinle vinham assumindo no estado de São Paulo, mediante a concessão do Porto de Santos. Entretanto, tal concessão não foi alterada, e, em 1902, os 
estudos da companhia apontavam para a utilização do rio Itatinga como o mais vantajoso para a produção de energia elétrica. Logo, a Light protestava que aquela cachoeira não poderia ser usada para outro fim que não fosse atender os serviços do Porto de Santos. Mesmo que a Docas de Santos fosse vinculada ao grupo de Guinle, a autorização da empresa não englobava o oferecimento de serviço de eletricidade em São Paulo. Isto é, a Companhia Brasileira e Energia Elétrica não podia usufruir a cachoeira de concessão da Docas, pois esta havia sido cedida pelo governo para gerar energia para o porto de Santos, e não para a comercialização de energia. Na imprensa o fato foi assim registrado:

Boatos de desordem: Ação contra a Companhia da Docas - As cachoeiras de Itatinga. Corre que o governo do Estado vai promover uma ação contra a Companhia das Docas, sobre a propriedade das cachoeiras de Itatinga, onde aquela empresa montou seus maquinismos para a distribuição de força elétrica a essa cidade. Esses terrenos, segundo se diz, são devolutos, e, portanto, de propriedade do Estado. Ao que parece, o Dr. João Carvalhal, subprocurador fiscal do Estado nesta cidade, já recebeu instrução do governo para iniciar a questão. ${ }^{34}$

Como descrito nos relatórios da Light, a Companhia Brasileira de Energia Elétrica não teria autorização para aproveitar o excedente de energia da usina de Itatinga, situada a $70 \mathrm{~km}$ da cidade de São Paulo, pois essa energia havia sido destinada em concessão federal apenas para o Porto de Santos. "Essa autorização foi dada à firma Gaffrée \& Guinle como concessionários da Docas de Santos" (SP LIGHT, 1909, p.49). Tal confusão ocorria porque os empresários Gaffrée e Guinle eram diretores de inúmeras empresas: a Docas de Santos, Sacaria de Juta, Companhia Brasileira de Energia Elétrica, entre outras, e, no entender da Light, isso não permitia juridicamente, que um bem de uma empresa fosse utilizada por outra. Principalmente quando essa associação de bens envolvia leis federais (como a permissão de uso de uma cachoeira). Assim, sendo a exploração 
da cachoeira de Itatinga autorizada por uma concessão federal para o Porto de Santos, a energia elétrica produzida naquela usina não poderia ser revertida para os serviços na cidade de São Paulo.

A Light poderia ter razão quanto à cachoeira de Itatinga, mas já percebia que enfrentar a Docas com essa justificativa não daria resultados. Afinal, esse mesmo relatório da empresa canadense de 1909 já atentava para a existência de outra cachoeira cuja concessão era da Companhia Brasileira de Energia Elétrica. A autorização para a utilização dessa outra cachoeira era de setembro de 1908, em que outra concessão do governo federal garantia à firma de Guinle \& Co. o uso e exploração de uma cachoeira, próxima a Itatinga, chamada Itapanhaú. A Companhia Brasileira de Energia Elétrica, por um decreto aprovado pelo governo federal, fora autorizada a realizar um plano de transmissão de energia de Itapanhaú para São Paulo, com o prazo de concessão de 20 anos de distribuição de energia elétrica. ${ }^{35}$ Desta forma, Guinle poderia servir a cidade de São Paulo; e, para se defender na imprensa, novos artigos apareceram respaldando a CBEE:

A Light quis fazer acreditar em S. Paulo ora que a cachoeira de Itapanhaú não pertencia aos proponentes, ora que os proponentes dariam energia elétrica da cachoeira de Itatinga, que pertence a Docas, ora que não dariam energia alguma e só pretendiam prejudicar $\mathrm{o}$ crédito da Light no interior e no exterior... De nada, porém, valeram as boas falas. A concessão foi dada. ${ }^{36}$

Nesse sentido, o argumento da empresa de Alexander Mackenzie não se sustentava mais. Independente da cachoeira, a Companhia Brasileira de Energia Elétrica poderia oferecer seus serviços a cidade de São Paulo, pois "a exploração dessa cachoeira foi concedida por um decreto ao Governo Federal que, por conseguinte, reconheceu-se tratar-se do bem que não lhe pertencia". ${ }^{37}$ Não sendo Federal, e sim particular, essa cachoeira poderia servir de usina para fornecimento de energia elétrica 
para São Paulo. Somava-se a este fato que nada impedia que a Docas de Santos vendesse o excedente de energia para qualquer outra empresa, e, no caso, para a companhia Docas de Santos. Mas ainda não estava tudo perdido para a Light: um recurso sobre a lei municipal $n^{\circ} 407$, de 21 de julho de 1899, lei sobre a concessão de energia elétrica na cidade de São Paulo, poderia garantir a vitória da Light, mas era preciso uma certa pressa, afinal a empresa de Guinle já estava quase pronta para entrar na cidade.

A Docas de Santos, nesse momento, precisava apenas elaborar um planejamento de como seria a instalação de seus equipamentos na cidade de São Paulo. Buscando evitar a concretização do plano de Eduardo Guinle, a São Paulo Light, recuperando a legislação sobre a regulação dos serviços de energia elétrica no município, começou a questionar o conceito de lugares ocupados. A lei municipal que determinava essa regulação era a Lei $\mathrm{n}^{\circ} 407$, de 21 de julho de 1899, que reafirmava o espírito da livre-concorrência. Mas como estava descrito no próprio relatório da companhia canadense de 1909, tal lei era passível de diferentes interpretações (SP LIGHT, 1909, p.52). O relatório da Light lembrava que, conforme o artigo 12 da presente lei, a prefeitura tinha o direito absoluto de conceder autorizações da mesma natureza nas mesmas áreas de concessão, excluindo aquelas cujos lugares já haviam sido ocupados. ${ }^{38}$ Com as diferentes formas de interpretação, era preciso uniformizar a interpretação da Lei $n^{\circ} 407$, e, para tanto, a Light procurou forçar a Câmara Municipal a redefinir o conceito de lugares ocupados:

Apelamos (Light) para a Câmara Municipal, um corpo composto de 16 membros, quem, depois de longos debates em diferentes sessões aprovaram a nova lei $\mathrm{n}^{\circ} 1210$, em 29 de abril de 1909, interpretando a anterior lei $\mathrm{n}^{\circ} 407$ sobre o conceito lugares. De acordo com tal lei, desta maneira, essa companhia tem agora o direito exclusivo até o ano de 1919 para colocar canalizações nas ruas já ocupadas (SP LIGHT, 1909, p.48-54). 
Afinal, o conceito que levantava dúvidas era o de lugares ocupados, que de um lado podia representar estritamente o limite físico da ocupação com postes, fios e objetos em geral da empresa já estabelecida, ou, de outro lado, o conceito de lugares ocupados, como era entendido pela Light, representava "todas as ruas, praças e vias públicas em que existam quaisquer tipos de canalização" (SP LIGHT, 1909, p.52). Essa era uma reprodução fiel da interpretação da lei de municipal $n^{\circ} 407$, de 21 de julho de 1899, em que a Câmara Municipal, por meio da nova definição de lugares ocupados de $\mathrm{n}^{\circ}$ 1210, publicada em 29 de abril de 1909, buscava regular mais adequadamente os serviços de energia elétrica. Isso significava que toda a região já pretendida pela Light para a ocupação, aquelas regiões que já possuíam as canalizações e projetos em andamento não poderiam ser concedidas a outras empresas. E, como a lei de 1899 garantia a concessão por vinte anos, até 1919, a Light tinha o direito de atuar com exclusividade em toda a região já atendida, o que impedia a Companhia Brasileira de Energia Elétrica de fornecer eletricidade para a quase totalidade da cidade São Paulo. Entretanto, tal decisão, que suscitou calorosos debates na Câmara Municipal entre os dias 21 e 24 de abril de 1909, repercutiu em violentas manifestações.

Percebendo a movimentação tomada pela empresa canadense na Câmara Municipal e nos meios de comunicação para sustentar o monopólio nos serviços urbanos, os estudantes das faculdades de Direito e Engenharia de São Paulo foram às ruas no dia 24 de abril de 1909 para questionar o parecer da Comissão de Justiça da Câmara dos Vereadores que ampliava os poderes da Light na capital (CARONE e PERAZZO, 1990, p.40-4). O público, que acompanhava das galerias da câmara o debate, vaiava os vereadores favoráveis a Light e aplaudia aqueles em defesa da livre-concorrência, apesar disso, a Light, com facilidade, acabou vitoriosa no pleito da Câmara Municipal: 12 votos contra apenas 3 entre os 16 vereadores. ${ }^{39}$

Ao mesmo tempo em que jornais como O Estado de São Paulo e A Notícia se posicionavam a favor da CBEE, questionando o poder do "polvo canadense" e relatando 
pequenos acidentes causados pelos bondes da Light para mobilizar a população (CARONE e PERAZZO, 1990, p. 40-4), os estudantes universitários enalteciam a prévia posição de Antonio Prado quanto à livre-concorrência. A Notícia comparava em seus artigos os serviços de eletricidade no Rio de Janeiro e em São Paulo, argumentando que Antonio Prado era um grande prefeito ao barrar o monopólio da Light, diferente do ocorrido no Rio de Janeiro, em que não existiam forças políticas suficientes para livrar a capital brasileira do monopólio canadense. Combatendo as estratégias políticas da Light, "o jornal acentua a posição límpida do prefeito, que afastava a tentativa de suborno proposta pelos diretores da Light" e se posicionando "contrário aos preços extorsivos cobrados pela Light - cinco vezes superior ao valor real". ${ }^{40} \mathrm{~A}$ participação de estudantes universitários em reivindicações era constante. Ainda em 1909, por meio de abaixo assinado, exigiam a redução dos preços das passagens de bondes em cinqüenta por cento, seguindo a redução que havia sido concedida aos estudantes das escolas secundárias e primárias. Estudantes da Poli e do Largo São Francisco e a população em geral, reunidos nas ruas centrais da capital, partiram para ofensiva nos dias 24 e 25 de abril, após a decisão municipal, contra o patrimônio da Light, aclamando: "Abaixo a Light! Abaixo o monopólio". ${ }^{41}$ Bondes eram apedrejados e assaltados e gritos de ordem eram pronunciados contra a empresa canadense e a Câmara Municipal, e nem mesmo o jornal A Gazeta, defensor da Light, ficou impune para a população. A manifestação somente foi abafada com a repressão da Guarda Cívica.

De qualquer maneira, mesmo com a decisão da Câmara, novamente o discurso liberal parecia ser hegemônico. Conforme o segundo artigo deste mesmo documento: "Fica a Prefeitura autorizada a modificar os contratos da The São Paulo Tramway, Light and Power Company Limited, para o serviço de força e luz, mediante vantagens de interesse geral que ela outorgue". A prefeitura mantinha plenos poderes para a autorização de novas concessões de energia elétrica, seguindo as necessidades do município, e "não só em relação a esse serviço, como e 
principalmente em relação ao de bondes, mantido o prazo do art. 12 da lei $n^{\circ} 407$, dado à concessionária para exploração da indústria de eletricidade como luz e força e que é de 20 anos". ${ }^{42}$ Desta forma, ficava clara a possibilidade de a municipalidade se reservar o direito de conceder a outras empresas a prerrogativa de participar do fornecimento da eletricidade, desde que se respeitassem os lugares já ocupados pela Light. Contudo, como o monopólio sobre a geração e distribuição da energia elétrica nos locais ocupados correspondia à cidade de São Paulo praticamente inteira, essa decisão da Câmara Municipal entrava em conflito com a disposição anterior do Prefeito Antonio Prado, a de autorizar a Companhia Brasileira de Energia Elétrica a fornecer energia para o mercado paulista.

Diante das posições antagônicas do poder executivo e do legislativo, e contra a interpretação da câmara que favorecia a Light, a Companhia Brasileira de Energia Elétrica entrou com um recurso no Senado, "contra a Lei $n^{\circ} 1210$, de 29 de Abril de 1909, da Câmara Municipal de Capital, que interpreta a lei $n^{\circ} 407$, de 21 de julho de 1899, da mesma Câmara". ${ }^{43}$ Alegavam que tal lei contrariava os preceitos liberais da Constituição Federal (artigos 3 e 72), a Constituição do Estado de São Paulo (artigo 55), a lei federal $n^{\circ} 1316$ (1905) e a lei orgânica dos municípios paulistas $\mathrm{n}^{\circ} 1038$ (1906). O Senado, contudo, resolveu "não tomar conhecimento do recurso interposto por Guinle \& Co., contra a lei declarada pela Câmara Municipal da capital". Por meio do parecer do Senado, redigido por Cesário Bastos e A. J. Pinto Ferraz, era problematizada a idéia de livre-concorrência para os serviços públicos, ponderando que os monopólios condenados pela Constituição Federal eram aqueles de "direito comum", que "cerceariam a posse e gozo geral de alguma coisa". Concluindo a argumentação:

Conceder, porém, um privilégio sobre objeto que não faz parte do domínio comum à atividade humana, que não é um direito de todos, não é propriamente constituir um monopólio condenado por esse princípio fundamental do direito público universal: assim, não é dado aos indivíduos o arbítrio de construir pontes 
LUZ, LEIS E LIVRE-CONCORRÊNCIA:...

sobre rios navegáveis, construir estradas sobre o território nacional, montar serviços públicos de barcos de passagem fluvial, organizar serviços para distribuição, nas cidades, de água, luz, esgotos, força ou outros para uso comum dos habitantes, ocupando-lhes o ar, a superfície ou o subsolo das ruas. Tais serviços não pertencem ao direito comum da atividade humana, não podem ser entregues à livre exploração individual, não cabem na esfera do comércio e da indústria, protegidos e assegurados a todos pela garantia constitucional são antes atributos da administração da União. ${ }^{44}$

Ao mesmo tempo em que tentava persuadir as diferentes esferas do poder político, sem muito sucesso, Eduardo Guinle iniciou nova campanha de defesa de sua empresa nos meios de comunicação. Em artigo do jornal Diário Popular, de 28 de abril de 1909, Guinle questionava a decisão da Câmara Municipal, que entrava em contradição com a decisão inicial do prefeito, dando aquela lei a possibilidade de monopólio, enquanto estava claro na lei de 1899 a possibilidade de novos concorrentes nesse serviço da cidade de São Paulo. Segundo interpretação do Senado, essas determinações não eram antagônicas no sentido em que a Light conquistava o privilégio para um serviço público. Mesmo assim, em resposta às acusações dos empresários da companhia Docas de Santos, o jornal A Gazeta, advogando os interesses da Light em São Paulo, respondia em defesa da empresa canadense:

a expressão lugares ocupados significa as ruas, praças e caminhos onde já existem canalizações de força e luz (...) Hoje, porém, o caso toca aos srs. Guinle \& Co., que aliás não devem sentir muito à vontade quando combatem os odiosos monopólios, ao se lembrarem da existência do Cais de Santos.

Mais que defender o princípio de monopólio natural, os defensores da Light estavam se referindo ao monopólio do Porto de Santos, revertendo a argumentação do controle monopolista para o principal porto de exportação de café do país, cujo controle era dos empresários concorrentes. Tal controle era 
bastante contestado por grupos da sociedade paulista, especialmente produtores de café e comerciantes de importação e exportação, que, além de depender dos serviços do porto, precisavam pagar altas taxas portuárias. Acima de tudo, ambos atores dessa disputa eram poderosos grupos capitalistas em busca de maiores mercados. O mesmo artigo termina considerando:

O que é certo é que a Light and Power tem um contrato firmado com a Municipalidade de S. Paulo, em virtude do qual the assiste exclusivo aos lugares ocupados pelas suas canalizações durante o espaço de 20 anos, e baseados nesses contratos os capitalistas estrangeiros mandaram seu rico dinheiro para São Paulo e a Companhia instalou o seu serviço, fazendo obras grandiosas, despendendo enormes somas de capital. ${ }^{45}$

Com a decisão da Câmara quanto aos lugares ocupados, só restava a Guinle uma possibilidade para vencer a batalha: que o prefeito Antônio Prado não aceitasse a interpretação da lei $\mathrm{n}^{\circ}$ 1.210 e procurasse solicitar sua reinterpretação. Afinal, havia uma divergência entre o poder legislativo e o executivo, e, como Antônio Prado era um prefeito de extremo poder e influência dentro da Câmara, sua pressão quanto à entrada da nova companhia poderia promover uma revisão da lei. Porém, diferente do que Guinle imaginava, o Prefeito acabou por aceitar a nova interpretação ao mesmo tempo em que revogava sua autorização, como relatava o jornal Diário Popular:

sobre a instalação e distribuição de luz e força elétrica dos lugares já ocupados, - o Dr. prefeito municipal, vendo cessada essa atribuição que a lei de 1899 lhe dava, não aprovou as plantas apresentadas pela firma Guinle e Comp., para a distribuição de energia elétrica nos 4 setores da cidade, e declarou sem efeito o seu despacho de 22 de fevereiro de 1909, pelo qual autorizava aquela firma a instalar o seu serviço de distribuição de força e luz elétrica. ${ }^{46}$ 
Deste modo, além de o Senado negar o recurso da empresa Guinle \& Co., o próprio prefeito Antonio Prado, que anteriormente havia autorizado a empresa brasileira a distribuir energia dentro da cidade de São Paulo, voltava atrás. Para tanto, o prefeito acabou por não aprovar as plantas, entregues pela CBEE para a comissão de obras da prefeitura em 30 de março, para a distribuição de energia em São Paulo (SP LIGHT, 1909, p.52). A contestação dos lugares ocupados não havia funcionado. Em meados de 1911, a Câmara Municipal dava seu posicionamento final sobre a questão dos lugares ocupados:

a Light and Power tem direito adquirido e expressamente mencionado no seu contrato, de colocar instalações para esse serviço em todas as ruas e praças da cidade, sem exceção alguma, dependendo o exercício desse direito do cumprimento das estipulações do mesmo contrato: conseguintemente, nenhuma outra autorização pode ser dada para o mesmo serviço para distribuição de luz e força elétrica nas ruas e praças da cidade, onde aquela empresa já tem direito adquirido para a colocação das instalações sem ofensa desse direito. ${ }^{47}$

Mas essa decisão por parte dos órgãos políticos não significava que os persistentes empresários donos da concessão do Porto de Santos estavam desistindo do setor de energia. Os Guinle continuariam a sustentar campanhas publicitárias contra o monopólio da Light, enquanto buscavam brechas nos aparatos legais para oferecer seu serviço, que, como sempre era lembrado, seria muito mais barato do que aqueles servidos pela Light. Por isso mesmo a companhia canadense não se descuidava: já estava em plena operação a aquisição acionária da companhia inglesa São Paulo Gás Co., liquidando qualquer possibilidade de que a concorrente brasileira assumisse alguma concessão na cidade.

Assim, a disputa entre a Light e a Docas de Santos diminuiu dentro dos jornais e da própria Câmara Municipal e Estadual nos ano de 1910 e início de 1911. Afinal de contas, Guinle \& Co. não tinha mais muita perspectiva de vencer a 
batalha diante do lobby da Light. Nesses dois anos, o relatório da Light relatava uma certa prosperidade da sociedade causada pelo sucesso da política de valorização do café, cujos resultados na economia haviam repercutido favoravelmente ao desenvolvimento da própria empresa canadense. Nesse sentido, a expansão do consumo de energia elétrica para fábricas e indústrias era sintomático: de 37.137 .230 kwh em 1909, a São Paulo Light passou a fornecer 48.918.390 kwh em 1910; um aumento de, aproximadamente, $33 \%$ de energia para fins industriais, o que ilustrava o considerável avanço industrial no período (SP LIGHT, 1910, p.1-8).

No ano de 1910, depois de dez anos de permanência de Antonio Prado na prefeitura de São Paulo, um novo prefeito havia sido eleito. Barão Raymundo Duprat assumia a cadeira da prefeitura e a Light, como não poderia deixar de fazer: "antecipamos uma relação bastante cordial com o novo administrador" (SP LIGHT, 1910, p.8). O contexto era de ampla modernização da cidade, com a construção de altos prédios, abertura de avenidas e construção de pontes, e a Light vinha participando de tal processo aumentando a geração de energia para a cidade e estendendo a iluminação urbana para novos bairros, com a ampliação da usina de Parnaíba. ${ }^{48} \mathrm{O}$ único problema citado em jornais era referente à seca registrada em São Paulo, causando, em meados de 1911, uma baixa do Rio Tietê e uma conseqüente restrição do atendimento de energia elétrica por alguns dias. Esse fato foi suficiente para que os Guinle voltassem a questionar os serviços da Light. O relatório da Light de 1911 dizia:

Esse ano, além das mencionadas extraordinárias condições de operação, foi notável os novos, e mais agressivos, ataques do grupo Guinle, o qual procurou todas as possibilidades de nos enfrentar para garantir com a municipalidade, o Estado e o governo Federal a licença de concessão (SP LIGHT, 1911, p.6).

Os engenheiros da Light, buscando solucionar a questão da falta de energia, tinham uma proposta para a diretoria da 
empresa. Mediante a necessidade de ampliar a produção de energia e de resolver as contendas com a concorrente, a Light deveria realizar a "mais importante negociação", que seria a compra de Itapanhaú. Tal ação significava que, além de adquirir uma boa fonte potencial de energia para uma nova hidrelétrica (35 a $50 \mathrm{mil} \mathrm{kw),} \mathrm{a} \mathrm{São} \mathrm{Paulo} \mathrm{Light} \mathrm{poderia} \mathrm{definitivamente}$ acabar com as pretensões da Docas de Santos de atender o mercado da capital do estado de São Paulo. Evidente que, naquele período, não havia interesse da companhia nacional de firmar um contrato de tal magnitude com a São Paulo Light, bem porque as perspectivas da Companhia Brasileira de Energia Elétrica de entrar no mercado paulista e carioca ainda existiam, especialmente no Rio de Janeiro, em que o contrato da Light findava em $1915 .{ }^{49}$

A demanda crescente de energia elétrica impunha à companhia canadense novos investimentos na construção de usinas hidrelétricas. Para tanto, no final de 1911, a São Paulo Light procurava ampliar o seu prazo de concessão dos serviços de energia elétrica na cidade de São Paulo, ainda que a empresa tivesse o direito de usufruir o privilégio de distribuição até 1919. Para a empresa, o presente prazo, menor do que uma década, não garantiria o retorno para os investimentos previstos: segundo a Light eram necessários mais 50 anos de concessão. Apesar desse pedido ter acontecido no mês de novembro de 1911, todo o debate sobre esse pedido se desenrolou no ano seguinte, com os antigos atores: de um lado a Light pressionando a Câmara para prorrogar o tempo de concessão, e de outro, Guinle \& Co. evitando mais essa vitória da Light, que acabaria com qualquer perspectiva futura para os empresários nacionais. Aumentando a concessão, a Light se comprometia a reduzir os preços em vigor e procurava oferecer novas vantagens ao público. ${ }^{50}$

A ampliação do prazo de concessão da cidade de São Paulo se ligava ao plano da Light de construção de um grande império da iluminação no Brasil. Afinal, a companhia canadense já estava instalada nas duas principais cidades brasileiras, São Paulo e Rio de Janeiro, e aos poucos ia expandindo suas áreas 
de atendimento, chegando à região de Sorocaba e do Vale do Paraíba. Ao mesmo tempo em que expandia as fronteiras de concessão, procurava criar um sistema de interligação dessas áreas, para garantir maior segurança contra problemas como falta de água e de energia em suas concessões. Esse amplo projeto levaria bastante tempo para ser implantado, e um dos pontos chaves para a concretização seria a construção da usina de Cubatão na década de 20. Tais investimentos, como a construção das maiores hidroelétricas do mundo, como eram os casos de Itupararanga (1914) e Cubatão (1925), e ligação de redes de transmissão por uma região extensa, exigiam altíssimos recursos para a época. Portanto, a Light só poderia se propor a financiar tamanhas obras com a segurança de que teria tempo e mercados garantidos para recuperar os investimentos; isso quer dizer, existiam duas condições básicas para a aceitação da Light para iniciar esse grande projeto: em primeiro lugar, a garantia de monopólio sobre os mercados e, em segundo lugar, a garantia de um prazo longo de concessão do serviço.

Tamanho controle que a Light passaria a ter na região, para grupos nacionalistas, como representado pelos protestos de Alberto Torres ao processo de desnacionalização do país, significava entregar a concessão de energia elétrica para uma empresa estrangeira que poderia impor inúmeras condições para um país dependente. O setor de eletricidade era um setor estratégico para o desenvolvimento, para a industrialização e urbanização; portanto, juntamente com a Docas de Santos, grupos nacionalistas lutaram contra a ampliação do poder da Light no país. Se de um lado a Companhia Brasileira de Energia Elétrica continuava a gastar esforços para entrar no mercado de eletricidade, de outro lado, no ano de 1912, uma nova empresa de energia elétrica, a Empresa de Força e Luz Norte de São Paulo, solicitou autorização à Câmara Municipal para atender o serviço de distribuição de energia para algumas áreas ainda não atendidas pela Light na cidade de São Paulo. ${ }^{51}$

Contra o pedido da Light de 1911, Guinle \& Co., durante todo o ano de 1912, defrontou-se com um grande problema: como evitar a dilatação do prazo de concessão da empresa 
concorrente? Mesmo com a morte de seu patriarca, Eduardo Guinle, no dia 9 de março de $1912,{ }^{52}$ a empresa manteve fortes pressões contra a Light. Para ainda ter alguma chance dentro do mercado paulista era preciso questionar de qualquer maneira a expansão da concessão da Light por cinqüenta anos e continuar exigindo a autorização para assumir as áreas não ocupadas. A defesa da Light se baseava nos benefícios que a empresa estava trazendo para a cidade de São Paulo, como o auxílio para a construção de viadutos, a construção de novas linhas e a ampliação dos repasses para o município. De outro lado, a Companhia Brasileira de Energia Elétrica buscava colocar lado a lado as tarifas das duas empresas para comprovar os abusivos preços da empresa canadense. $\mathrm{Na} 20^{\circ}$ sessão ordinária da Câmara Municipal, de 13 de março de 1912, uma representação da Companhia Brasileira de Energia Elétrica dos Srs. Guinle \& Co. relatava que os preços máximos cobrados pela empresa nacional eram de 200 réis o kwh para os serviços de luz, e 100 réis para kwh para as pequenas indústrias e para o uso doméstico. Enquanto isso, os preços da Light com desconto já deduzidos eram cerca de 375 réis o kwh para os consumidores de energia, e 250 réis kwh para o consumo de pequenas indústrias e uso doméstico. ${ }^{53}$

Já no O Estado de São Paulo, a Companhia Brasileira de Energia Elétrica em longo artigo, questionava, entre outros fatos, a ampliação da concessão da Light por mais cinqüenta anos: "sem reversão dos serviços no fim desse prazo, sem revisão periódica de tarifas para a sua redução de acordo com os progressos da indústria de eletricidade, e quase sem fiscalização". ${ }^{4} \mathrm{E}$ ainda, consideravam os empresários que a empresa canadense, hipocritamente, oferecia alguns benefícios para a cidade de São Paulo, como a construção de viadutos, a transferência de $2 \frac{1}{2}$ por cento da receita da empresa para a prefeitura, ${ }^{55}$ e a redução das tarifas dos serviços de bondes e de distribuição de energia elétrica, sem que se discutisse os termos do contrato de renovação e os valores das tarifas em comparação com o que a Companhia Brasileira de Energia Elétrica oferecia. 
Conforme a resposta da São Paulo Light ao jornal O Estado de São Paulo, a empresa não havia se comprometido previamente com a municipalidade em oferecer reduções de tarifas, nem em construir viadutos, nem mesmo em construir novas linhas de bondes, como sugeria o artigo de Guinle \& Co. Eram todos benefícios extras que a empresa proporcionava para a capital. E, acima de tudo, os diretores da Light consideravam "os preços que eles (CBEE) oferecem no ar, são absolutamente inaceitáveis. A empresa que os adotasse havia de arrebentar forçosamente". Utilizando os custos de equipamentos mediante os valores fornecidos pela loja de aparelhos elétricos de Guinle \& Co., o superintendente $\mathrm{N}$. Walmsley afirmava a impossibilidade de os concorrentes oferecerem serviços por preço máximo de 40 réis por kwh para iluminação pública, "isso sem incluir o consumo de energia, o custo de instalação, a depreciação do material, as despesas de fiscalização, as despesas gerais etc". ${ }^{56}$ Em suma, no entender da São Paulo Light, a estratégia de sua concorrente era persuadir a população de que a empresa canadense estava em território nacional para espoliar o povo brasileiro. Afinal, conforme dados apresentados pela empresa canadense, no Brasil, oitenta e sete cidades mantinham preços para luz entre 300 e 600 réis e para força entre 150 e 600 réis, enquanto na Inglaterra o preço médio para energia elétrica para luz estava ao redor de 215 réis, e na Alemanha entre 320 e 560 réis: logo, com a redução das tarifas, a Light estaria com valores em patamares aceitáveis.

Além da questão do valor das tarifas, a crítica de Guinle \& Co. contemplava os termos utilizados na revisão dos contratos. Para a empresa nacional, a prefeitura, ao renovar a concessão por mais cinqüenta anos, não tomava as devidas precauções em restringir o poder da São Paulo Light e, conseqüentemente, de criar mecanismos de defesa para a população. Como ressaltava em carta ao jornal, a Companhia Brasileira de Energia Elétrica:

deixou ontem de réplica ao Sr. W. Walmsley (superintendente da São Paulo Light) porque devia dirigir-se à Câmara Municipal para firmar alguns pontos essencialíssimos, que até hoje não foram 
tomados em consideração pela Comissão de Justiça, e sobre os quais a Light and Power nunca quis articular uma só palavra: 1) Revisão dos preços, no interesse do consumidor, em determinadas épocas; 2) Reversão das instalações ao patrimônio municipal no fim do prazo do monopólio; 3) Encampação em condições previamente ajustadas; 4) Fiscalização eficaz e rigorosa dos contratos. ${ }^{57}$

Essas exigências da companhia Docas de Santos estavam balizadas pelo decreto federal $\mathrm{n}^{\circ} 5.407$, de 27 de dezembro de 1904, que estabeleciam as regras gerais para concessões de aproveitamento de energia elétrica: máximo de noventa anos para concessões; concessões sem privilégio; reversão para a União dos bens utilizados na concessão, sem indenização; remuneração máxima de $12 \%$ de lucros líquidos frente ao capital aprovado pelo governo e revisão tarifária ao final do terceiro ano de concessão, e depois de cinco em cinco anos. Mas, tratando-se de uma concessão municipal, e segundo as leis do município de São Paulo, que davam plenos poderes para o prefeito decidir sobre tal pleito, os Guinle questionavam por que, mesmo sendo "estas condições (...) verdadeiros dogmas em matéria de monopólios", não eram discutidas. E, comparando preços e rendas das duas empresas, concluía-se que o público em geral economizaria anualmente cerca de $484: 716 \$ 452$ réis com os serviços prestados pela companhia nacional. Assim, mesmo com as contribuições $2 \frac{1}{2}$ por cento da Light para a municipalidade, a economia proporcionada pela empresa concorrente seria maior, e quem pagaria por esse valor seria a população:

Diz o Sr. Walmsley, discutindo com as cifras do seu balanço do ano passado, que o $2 \frac{1 / 2}{2}$ por cento da sua renda bruta dariam à Câmara, em 1911, 312:500\$000 de lucros. Sempre a mania de o propósito de exagerar os algarismos para deslumbrar o próximo, como se este povo não tivesse aprendido o a,b,c! Aqui temos o relatório geral em Toronto (Canadá): consta que a renda bruta da Light em 1911 foi de \$3.595.277,91. Feito o cálculo da porcentagem, vê-se que os $2 \frac{1 / 2}{2}$ por cento estão muito abaixo dos tais 312:500\$000! 
Mas a Light pouco se importa que todos os dias lhe estejamos a endireitar os algarismos e contas... O que ela quer é impor a sua vontade e seu poderio, a sua ambição. Dêem-lhe o monopólio de 50 anos, sem revisão de tarifas, sem encampação, sem fiscalização e sem multas, assine esse cobiçado contrato eterno, e verão todos como a Light e os Sr. W. passam a virar as suas avessas sua matemática! ${ }^{58}$

A "réplica final" da Light reafirmava o privilégio da empresa canadense por ao menos mais nove anos, conforme contrato de 1899, e considerava que: "a São Paulo Light fez a Câmara uma proposta honesta. Tendo ainda privilégio de 29 anos para bondes e 9 para força e luz, pediu uma prorrogação de 21 anos, para bondes, e a equiparação do privilégio de luz e força ao de bondes". Em contrapartida, conforme requerimento enviado para a Câmara Municipal, ofereciam ao público: 20 por cento de redução do preço básico da luz, 33 por cento de redução nos preços máximos de energia elétrica e, serviço de segunda classe para bondes, na proporção de 1/3 dos carros de primeira classe, ao preço de 100 réis nas horas favoráveis aos operários, a juízo da prefeitura. E à Câmara Municipal: oferecia $2 \frac{1}{2}$ por cento de contribuição anual sobre a renda bruta total de bondes, força e luz; oferecia também o encargo de irrigar a cidade nas ruas em que circulam os bondes, de construir novas linhas de bondes, de contribuir com 300:000\$000 para construção de 2 viadutos sobre a ferrovia inglesa e de aumentar o número de passes para os serviços municipais. Em suma, garantiam os diretores da Light que os benefícios para a população eram muito maiores que puramente financeiros:

Eis ai, os dois termos da equação. Compare-os o público a luz do simples bom senso; julgue-os a Câmara, como zeladora que é do interesse dos municipais, e seja a questão resolvida com sabedoria. Mas, por Deus, não se preste ouvidos a argumentos de suspeitos e interessados, não já em negócios, mas em perturbar, seja como for, os direitos da Light. E temos concluído. ${ }^{59}$ 
LUZ, LEIS E LIVRE-CONCORRÊNCIA:...

Apesar de todas as acusações da Companhia Brasileira de Energia Elétrica, apesar das vantagens oferecidas e apresentadas aos meios de comunicação, apesar dos preceitos da livre-concorrência na legislação brasileira e, apesar da constante luta dentro da Câmara Municipal para evidenciar os benefícios que um sistema de concorrência poderia trazer para a cidade, a Light, novamente, apareceria com boa vantagem nos pleitos decisivos. Em primeiro lugar, o então prefeito Raymundo Duprat era velho aliado da empresa canadense ${ }^{60}$ e, em segundo lugar, mais uma vez a Câmara Municipal de São Paulo mantinha uma forte base aliada pró-Light.

Poucos eram os vereadores que pareciam se colocar contra a ampliação dos contratos da empresa. E ainda, aqueles que conhecidamente eram críticos da companhia canadense eram acusados pelos jornais de terem de se ausentado nos principais pleitos, por causa de subornos da Light, como o caso do vereador Carlos Garcia. Em sua defesa, o vereador ao retornar à Câmara discursou:

Quando resolvi partir de S. Paulo, a fazer uma pequena viagem para descanso e tratamento de saúde, discutia-se na Câmara Municipal um requerimento da Light and Power. (...) A verdade é que, no estrangeiro, vim a saber, por maledicentes e caluniadores, que a Câmara Municipal estava subornada à Light e que grandes quantias tinham sido despedidas com os vereadores da Câmara Municipal e até com o próprio sr. Prefeito. (...) Mas eu, que não tinha tomado parte na discussão, fui alvo de maledicências, porque disseram que sendo eu contrário às pretensões da Light, tinha sido arredado daqui por influência dela. Ora, isto é atirar uma pecha sobre vereador que absolutamente não tinha intervindo no debate. ${ }^{61}$

O amplo apoio era resultado posição da Light, que participava ativamente do projeto de modernização das elites paulistanas. O parecer da Comissão de Justiça da Câmara Municipal de São Paulo de maio de 1912 defendia a presença da companhia Light and Power, pois instalada com grandes capitais, para os vereadores, vinha cooperando 
"incontestavelmente para o desenvolvimento sempre crescente e vertiginoso desta cidade; considerando que o seu serviço de bondes é um dos melhores de todas as cidades da América". Especialmente, uma vez que a Light contribuiria "com grandes somas para diversos melhoramentos para a capital de S. Paulo, além de dar anualmente uma porcentagem de sua renda bruta a Câmara, concorrendo para os cofres do município com cerca de 40.000 contos". Essa vantagem era apreciada como um potencial recurso financeiro para que a Câmara pudesse financiar mais obras no projeto de urbanização da cidade. Então, o parecer da Comissão de Finanças, composta pelos vereadores Mario do Amaral, Oscar Porto e Francisco Paes de Barros, reafirmava a importância da Light para o município: "parece vantajosa para os cofres municipais a proposta apresentada pela The São Paulo Tramway, Light and Power Company". ${ }^{2}$

A Câmara Municipal mantinha sua posição central dentro de todo esse debate sobre o fornecimento de energia elétrica na cidade de São Paulo. Por isso ter um estreito relacionamento com os políticos municipais era instrumento fundamental para garantir vantagens dentro do município. Como observado anteriormente, previamente aos conflitos entre a Light e a companhia Docas de Santos, a empresa canadense havia iniciado sua operação em São Paulo por meio da consolidação de monopólios no mercado paulista, passando por cima de leis, como ao questionar o contrato de unificação da Viação Paulista, que dava privilégio do transporte à empresa nas áreas já servidas. A Light não somente conseguiu vitórias nos tribunais com apoio do advogado Carlos de Campos, como forçou o fechamento da Viação Paulista pela aquisição de suas dívidas (SILVA, 1986, p.34-5). E ainda, por meio da compra da maioria das ações da Companhia Água e Luz, em Assembléia Geral elaborada no dia 31 de maio de 1900, pôde formar uma diretoria própria para controlar os serviços de eletricidade. A nova diretoria era composta pelo advogado da Light Carlos de Campos, pelo ex-presidente do Estado de São Paulo, Fernando de Albuquerque, e o engenheiro e amigo de Pearson, Octavio Pacheco e Silva (SOUZA, 1982, p. 35), cuja particularidade era de 
LUZ, LEIS E LIVRE-CONCORRÊNCIA:...

ser comandada por membros da elite paulista, medida que aparentemente tornava-se uma estratégia da empresa canadense para compor com grupos políticos locais. Essa lógica era reafirmada no primeiro relatório anual da São Paulo Light, remetido para o Canadá em 1902, em que diretores canadenses no Brasil pediam a distribuição das novas ações da empresa para cidadãos "proeminentes" (1902, p.7).

Carlos de Campos, por exemplo, advogado da Light e político paulista, foi personagem decisivo na defesa da empresa canadense em diversos embates. Em meados da década de 1920, com a emergência de novos meios de transporte, como os ônibus e propostas de transporte subterrâneo, a Light enviou às instâncias governamentais um pedido para a formação de Plano Integrado de Transportes. Novamente Carlos de Campos endossava o documento, e, como presidente de Estado, ampliava a aprovação do projeto que recuperaria o monopólio dos transportes para a Light. ${ }^{63}$ Entretanto, com o falecimento do eminente aliado em 1927, a Light sofreria sua primeira grande derrota na Câmara Municipal: estava marcado o início de novos tempos. A ascensão de Pires do Rio para a prefeitura de São Paulo, de Júlio Preste para o governo estadual, e de Washington Luís para a presidência iniciaria os tempos dos transportes derivados de petróleo, o que geraria um contínuo desinteresse da Light pelos serviços de transporte, e uma ênfase maior nos serviços de eletricidade (MENDES, 1991, p.56).

\section{Participação dos bondes na receita da São Paulo Light - 1900-1945}

\begin{tabular}{|c|c|c|c|}
\hline Ano & $\begin{array}{r}\text { \% na } \\
\text { receita total }\end{array}$ & Ano & $\begin{array}{c}\% \text { na } \\
\text { receita total }\end{array}$ \\
\hline 1900 & 62,9 & 1925 & 47,6 \\
\hline 1905 & 71,3 & 1930 & 37,2 \\
\hline 1910 & 67,8 & 1935 & 29,5 \\
\hline 1915 & 59,5 & 1940 & 26,4 \\
\hline 1920 & 58,2 & 1945 & 21,7 \\
\hline
\end{tabular}

FONTE: SP LIGHT. Annual Report, 1900-1945. 
O mecanismo de composição política da Light com a elite paulista era muito eficiente para possibilitar maior trânsito dos interesses canadenses nos meios políticos. Os investimentos crescentes, juntamente com o poder político que a empresa canadense vinha consolidando, não só na cidade de São Paulo como até mesmo no Distrito Federal com a ampliação da empresa para o Rio de Janeiro no ano de 1905, parecia dar condições para empresa assumir monopólio dos serviços públicos nos principais mercados brasileiros. Raul Fernandes, importante acionista da companhia Docas de Santos, questionava tal poder da Light frente às decisões públicas. Afinal, depois de inúmeros embates judiciais entre a Light e as empresas do grupo de Guinle \& Co. sobre a questão de energia elétrica, os empresários nacionais não haviam tido êxito em nenhuma deliberação:

A companhia Brasileira de Energia Elétrica dos srs. Guinle anda realmente sem sorte. Toda a gente está farta de saber que eles mantêm com a São Paulo Light and Power uma infinidade de questões judiciais e nunca obtiveram sequer uma sentença a seu favor! Isto prova que a companhia dos srs. Guinle não tem sombra de direito algum. Ainda agora acaba a companhia dos srs. Guinle, de sofrer uma formidável derrota. Eles vivam propondo-se a fazer em São Paulo diversos serviços de energia elétrica, baseando-se em atos que o governo federal lhes havia expedido em 1908, referentes ao aproveitamento de uma cachoeira a que denominaram de Itapanhaú. A São Paulo Light and Power, vendo nesses atos federais um flagrante atentado contra os seus direitos exclusivos e contra a autonomia municipal, intentou uma ação para anular todos os atos federais expedidos a favor da companhia dos srs. Guinle. O juiz federal Sr.dr. Raul Martins pronunciou-se ontem a respeito, julgando procedente a ação proposta, dando assim ganho de causa a São Paulo Light and Power Co. Ltd. e condenando a companhia dos srs. Guinle nas custas. ${ }^{64}$

Se de um lado a Companhia Brasileira de Energia Elétrica recebia apoio dos intelectuais e políticos nacionalistas, a Light 
LUZ, LEIS E LIVRE-CONCORRÊNCIA:...

tinha um grande apoio difundido na sociedade, graças à eficiente propaganda através dos meios de comunicação e aos mecanismos de penetração nas instituições políticas. As decisões da Light eram muito respeitadas, pois a empresa dominava uma série de serviços urbanos. Assim como o prefeito Antônio Prado recuou diante da Light, muitos políticos acabavam deixando de questionar todo aquele poder, pois, a empresa canadense auxiliava governos com a construção e modernização de regiões da cidade. Outro importante meio de poder exercido pela Light dentro da Câmara foi seu eficiente mecanismo de lobby, que ultrapassava a relação pessoal entre políticos e funcionários e adentrava inclusive o sistema eleitoral. O jornal O Commercio de São Paulo denunciava o poder dos diretores da Light sobre a organização dos trabalhadores:

Já ontem deixamos bem esclarecido como o superintendente da Light intervinha na administração interna e economia da Sociedade Beneficente dos Empregados da Light. Essa intervenção começou primeiro pela imposição de um candidato seu para presidente da sociedade. Já vimos como os trabalhadores, os rudes proletários, fundadores e sustentáculos da Sociedade, responderam a essa despótica e absurda intervenção - a derrota do candidato oficial duas vezes sucessivas. Vimos também como esse ato de nobre independência foi acolhido pelo superintendente - a revogação de duas assembléias gerais, legalmente realizadas de acordo com as letras do estatuto. ${ }^{65}$

Existia dentro da Light uma grande preocupação dos funcionários do alto escalão, como diretores e superintendentes, em exercer domínio sobre os empregados, evitando greves e grandes manifestações dentro da empresa. De outro lado, era importante ter controle sobre os funcionários, principalmente durante as eleições, para garantir a vitória de certos vereadores que viriam auxiliar a Light nas decisões da Câmara. As eleições nesse período tinham um número de eleitores muito pequeno, e a Light, obrigando seus trabalhadores a participar das eleições, podia eleger facilmente alguns candidatos. Alberto de Faria, 
defensor das empresas nacionais, buscava atentar os governantes para essa formação dos "currais eleitorais" na cidade. Partindo dos argumentos de Alberto de Faria, do Jornal do Commercio, o Estado de São Paulo voltava a atacar o Polvo Canadense:

"A Light arregimenta forças para dar batalha à política dominante de São Paulo e não faz mistério que no próximo pleito, depois de ter alistado eleitores do seu enorme pessoal, reunirá maioria na Câmara Municipal dessa capital para a prorrogação monstruosa dos privilégios que uma vergonhosa lei interpretativa (Lei sobre os Lugares Ocupados) lhe deu".

O Sr. Alberto de Faria é um homem conhecido. É um grande capitalista e um cavalheiro de conceito. A suas palavras não se pode negar peso. Diante da denúncia gravíssima que lhes encerram, julgo-me no direito de formular estas duas perguntas para o meu governo e para as pessoas que me usam: Primeiro: A comissão de alistamento está de olho aberto? Segundo: Os chefes políticos da capital estão acordados ou dormindo? ${ }^{66}$

Enquanto isso, campanhas no jornal O Commercio também tentavam denunciar as estratégias da Light para conquistar maior poder dentro dos centros de decisão:

Quem é admitido na Companhia tem que se alistar eleitor, por bem ou por mal, seja estrangeiro ou nacional. Mas, quando ela despede um operário ou quando ele se despede, vai-se o cidadão de mãos limpas. A Light retém-lhe o título, como retém os títulos dos que estão enfermos, dos que morrem, dos que se ausentam (...). Amanhã, para vender um pleito, para eleger os seus apaniguados, para ter prefeitos ou vereadores que lhe façam novas concessões ou que a desonerem de suas obrigações, não tem necessidade de retirar do serviço um só de seus operários. Como lhes extorquiu os títulos, entrega-os a chefes, que os distribuem para indivíduos que não são eleitores. $\mathrm{O}$ número de votos, obtidos por esse baixo processo, há de influir na vitória definitiva (...). Essa companhia... dispõe, hoje, com segurança, de mais de mil títulos, que equivalem a mil eleitores. 
LUZ, LEIS E LIVRE-CONCORRÊNCIA:....

E continuando as denúncias, o jornal dizia:

Light, convertida em núcleo eleitoral, tem no Congresso do Estado, nas próprias repartições municipais, quem a auxilie, quem lhe dê apoio, quem a incite a prosseguir na sua intervenção imoral em nossa política. Entre os cúmplices, comparsas da Companhia... há alguns que se incumbem de alistar eleitores e dividi-los por seções... Em vésperas de eleições, os diretores da Light... comprometem-se a dar a este ou àquele candidato determinado número de votos. ${ }^{67}$

$\mathrm{Na}$ cidade de São Paulo o colégio eleitoral ainda era extremamente restrito, com apenas cerca de 11 mil eleitores, e a Light com seu poder econômico e mais de "mil alistamentos" acabava por influir decisivamente na eleição para vereadores, prefeito, deputados e até mesmo presidente de estado (SEGATTO, 2002, p.211-3). Nas palavras do jornal O Estado de São Paulo a "Light era um Estado dentro do Município". 68 presidente de estado eleito com apoio da Light, Albuquerque Lins, era descrito pela empresa como "um homem bem conhecido da Companhia, e acredita-se que a atitude do novo governo será de manter as justas e agradáveis relações" (SP LIGHT, 1907, p.8).

Desta forma, a Light mantinha sua capacidade de seduzir a população com a modernidade e os políticos com o poder dos lobbies. Abertamente a Light propunha auxílios financeiros à Câmara Municipal, e essa boa relação diplomática com vereadores e prefeito garantia maior autonomia para a empresa poder se desenvolver. Em ofício à Câmara Municipal, datado de 14 de agosto de 1911, Alexander Mackenzie, superintendente da Light, além de defender os motivos para a revisão dos contratos (ampliando-os para mais 50 anos), colocava abertamente que a Light estava disposta a conceder favores para a prefeitura e, até mesmo, individualmente para alguns vereadores. A defesa dos interesses lightianos na Câmara Municipal garantia determinados traçados dos trilhos dos bondes para alguns vereadores, como para os loteamentos de José Oswald Nogueira 
de Andrade $^{69}$ em Santa Cecília e Campos Elíseos (BARROS, 1995). ${ }^{70}$ Já a partir de 1915 , a empresa que seria bastante beneficiada pelos projetos das linhas de bondes da Light seria a City of São Paulo Improvements, empresa inglesa de urbanização, cujo comitê administrativo era também composto por diretores da Light (PASCHKES, 1986).

Em relação ao transporte urbano, a Light aceitava uma reivindicação da prefeitura, ampliando o número de carros de segunda classe para as regiões de circulação de operários e ainda aumentando o número de passes mensais para o transporte da municipalidade. A Light ainda seria responsável pela irrigação de ruas, "de acordo com propostas em ofícios para esse fim já feitas pela Companhia á Municipalidade. Esse serviço será gratuito." E, em relação ao serviço de força e luz, a Light se responsabilizaria "com a obrigação da Companhia manter a presente tabela de descontos de 25 por cento a 50 por cento." Por fim, além de todos esses favores concedidos, a empresa canadense ainda se comprometia em contribuir anualmente para a Municipalidade com 100 contos de réis, com mais os $2 \frac{1}{2}$ por cento da renda anual. ${ }^{71}$ Esse poder de lobbies e barganha era uma inegável qualidade de Light em São Paulo, que através desse mecanismo, e do próprio apoio de políticos da câmara, acabava por arregimentar vitórias em diversas questões. Para cooptar não só as instituições políticas, mas a população também, a Light propôs uma série de medidas que auxiliavam a Câmara Municipal além de beneficiar a população, as quais incluíam: investimentos para obras de melhoramento da cidade, como com a construção do Viaduto do Chá, e promover uma nova redução nos preços dos serviços de energia elétrica. ${ }^{72}$ Mas a empresa nunca perdeu de vista seus investimentos para a cooptação da elite paulista: o Viaduto do Chá, por exemplo, era a "chave" para conquistar o monopólio do transporte, conseguindo garantir a ligação da Praça da República com a Praça da Sé, duas áreas densamente povoadas.

Os debates de 1912 ficariam no ar, sem que novas discussões fossem retomadas nos anos subseqüentes. Carlos Garcia, vereador acusado de viajar durante as discussões de 
LUZ, LEIS E LIVRE-CONCORRÊNCIA:...

meados de 1912, no final do ano considerava que seria impossível que a Câmara tomasse alguma atitude sem que antes o Senado se posicionasse quanto aos termos da lei $\mathrm{n}^{\circ} 1.038$ de 1906, que autorizava o município a firmar concessões para "obras e serviços que dependam de grandes capitais sem limitação de prazo". ${ }^{73}$ Desmobilizando a discussão na Câmara, e sem que esta fosse levada ao Senado, a vitória da São Paulo Light pareceria ter sido consolidada, liquidando com as possibilidades de que seus concorrentes entrassem no mercado de São Paulo. Afinal, conforme a revisão dos contratos sobre os "lugares ocupados", a Light ainda tinha privilégio até ao menos 1919, e tudo levava a crer que a unificação de seus contratos de transporte e iluminação e a ampliação do período de monopólio por mais 50 anos seria aprovada. A prorrogação da concessão por mais cinqüenta anos era o início da concretização do plano da empresa canadense para construir, então, um império dos serviços públicos no Brasil, fundando já no ano seguinte, em 1913, a Brazilian Traction Light and Power Co. Ltd., que reunia as concessões de São Paulo, Rio de Janeiro e outras cidades secundárias. ${ }^{74}$

Os interesses da família Guinle não avançariam o necessário para que fossem autorizados a instalar os serviços públicos na capital paulista. Vale lembrar que, como visto no capítulo anterior, com a eminência das derrotas, a Companhia Brasileira de Energia Elétrica chegou a fazer reuniões com os dirigentes da companhia canadense para vender parte de seu material. Em 1915, com a ampliação da concessão da Light no Distrito Federal, estava claro para os empresários nacionais que não seria mais crível a justificativa da livre-concorrência para adquirir parcelas dos mercados das principais capitais brasileiras. Ademais, o contexto de Primeira Guerra Mundial com o encarecimento da importação de materiais e uma ligeira redução no consumo de energia elétrica tornava menos interessante os investimentos no setor de serviços. Nesse sentido, os agressivos conflitos ocorridos pré-Primeira Grande Guerra não seriam mais repetidos entre as empresas em fins da década de 1910. 


\section{Monopólio canadense e a preocupação municipal com a fiscalização dos serviços}

E foi durante o período de guerra que a São Paulo Light reafirmou a tendência anteriormente verificada de que os serviços de distribuição de energia elétrica e iluminação assumissem maior participação na receita da empresa. Excluído o ano de 1914, em que foram registrados maus resultados em decorrência de falência de alguns industriais (16 representando menos 6.341 HP vendidos), a tendência do período de guerra foi a ampliação do parque industrial, principalmente porque a São Paulo Light, em vez de se valer da cláusula-ouro, ou retirar os benefícios para industriais, manteve preços com descontos entre 25 e 50\%, estimulando a ampliação do consumo. Mesmo assim, a empresa havia tido uma redução de cerca de $12 \%$ da quantidade de ouro em comparação com o ano de 1913 (SP LIGHT, 1924, p.8 e 12). Puxado pelo crescimento industrial do período, a economia paulista já nos anos de 1917 e 1918 parecia viver um período de expansão econômica, atestado pelo crescimento das receitas da São Paulo Light "em todos departamentos". Isto é: mais pessoas estavam andando de bondes, maior era o número de consumidores de iluminação particular, a cidade vinha expandindo também a iluminação pública, e maiores eram os consumidores de energia elétrica para fins industriais. ${ }^{75}$

Assim, na passagem para a década de 1920 a soberania da Light estava garantida nos serviços públicos da capital. De qualquer maneira, conforme o contrato de 1899, em 1919 chegava ao fim o período de exclusividade a que a Light tinha direito nos lugares ocupados, sendo mantido, em contrapartida, o direito de "propriedade e exploração industrial". O regime de livre-concorrência, tão exigido pelos concorrentes nacionais, estava plenamente assegurado por lei, mas já não havia mais interesse do grupo pelo setor.

Entretanto, o fim do prazo de concessão da Light não passou em branco nos debates na Câmara Municipal de São Paulo. Em 13 de setembro de 1919, o vereador Almeirindo Gonçalves lembrava ao plenário que o privilégio da concessão 
da São Paulo Light com a capital findava ao dia 28 do corrente mês. E, portanto, segundo o vereador, era necessário realizar uma profunda discussão sobre os serviços públicos que competiam à Câmara Municipal a responsabilidade de legislar. Almeirindo considerava que não deveria se discutir a questão da livre-concorrência e que, afinal, já estava plenamente comprovado que, para a indústria de energia elétrica, o regime de concessão era o mais correto. Bem porque, fora as possíveis confusões de mais de uma empresa servindo a mesma localidade, a tendência seria de que a empresa mais "forte" assumisse o monopólio por oferecer serviços mais baratos segundo a idéia de economia de escala. Em síntese: "os trusts de serviços municipais constituem monopólios inevitáveis". Mas Almeirindo ia mais longe em sua argumentação, e afirmava: " $A$ providência que me parece mais adequada é decretar-se a desapropriação das instalações da concessionária para o fornecimento de força e luz". ${ }^{76}$ O Projeto $\mathrm{n}^{\circ} 69$ de 1919, de desapropriação das propriedades da Light, também determinava que nenhuma outra concessão seria estendida para qualquer empresa privada. Para o vereador o caminho desejável era a municipalização dos serviços, pois diferente dos interesses das empresas particulares que "visam principalmente seu interesse imediato", o poder público poderia efetivamente defender o interesse comum, atendendo bairros pobres que até então estavam legados às escuras.

O projeto de municipalização dos serviços de energia elétrica não seria levado a frente, contudo parte dos vereadores estava decidida a reduzir o poder da companhia canadense na cidade de São Paulo. Para tanto, os vereadores buscavam criar medidas que fiscalizassem os serviços da companhia, tornando o governo não apenas o poder concedente, mas também fiscalizador dos serviços públicos. ${ }^{77}$ Por exemplo, o vereador José Piedade exigia a criação de uma seção técnica que seria responsável exclusivamente pela fiscalização dos serviços de eletricidade prestados pela Light na diretoria de obras e viação do município. Para o vereador, essa determinação era fundamental para legitimar o controle dos serviços, afinal quem 
prestava a fiscalização de tais serviços elétricos eram os próprios funcionários da empresa canadense. Entre os anos de 1919 e 1920, inúmeras denúncias de problemas na prestação de serviços de bondes e iluminação foram levados à Câmara Municipal. O vereador José Piedade reclamava da falta de leis claras para o controle dos serviços públicos, e afirmava: "nenhuma cidade da Europa e da América do Norte, onde tão grandemente se tem desenvolvido a indústria da eletricidade, deixa de possuir leis especiais reguladoras". ${ }^{78} \mathrm{Em}$ apoio a Piedade, o vereador Marrey Junior acreditava que era necessário apoio dos Institutos de Engenharia e dos Advogados para "esclarecimentos dos doutos" e "tomar a iniciativa, nesta Câmara, de legislar sobre as prescrições (...) a que deverá ficar ou continuar sujeita a Light". ${ }^{79}$

O vereador Luciano Gualberto, de sua parte, lembrava dos inúmeros acidentes ocorridos com os bondes da Light, exigindo a mudança de nome da empresa para "Empresa Funerária de S. Paulo". ${ }^{80}$ O vereador achava que exista em São Paulo "um poder soberano", como "um déspota pior que Trostky e Lênin, um absolutismo mais absoluto que o Kaiser na Alemanha de ontem", e que "essa hidra de cem mil tentáculos chama-se Light and Power". ${ }^{81}$ E por isso, assim como os vereadores Luiz de Anhaia Mello, Marrey Júnior, Mario Craccho, Almerindo Gonçalves e José Piedade, Luciano Gualberto era favorável a uma rígida regulamentação dos serviços e sua consecutiva fiscalização. ${ }^{82}$

Além da crescente fiscalização dos órgãos governamentais e a pressão para uma prestação de serviços de maneira mais adequada, em meados da década de 1920, a Light teria outro grande problema para resolver. Nos anos de 1924 e 1925, uma longa estiagem no estado de São Paulo reduziu sobremaneira os reservatórios da companhia, gerando uma crise energética que culminaria com a falta de energia em alguns dias na capital. A prefeitura chegaria a determinar certas restrições, como a redução do número de bondes, a proibição da iluminação de fachadas, anúncios luminosos e jardins, além da restrição do consumo de iluminação e energia elétrica. ${ }^{83}$ Tal situação levou a São Paulo Light a iniciar a construção da usina de Rasgão, que 
seria entregue em tempo recorde, e a passar a comprar energia elétrica da usina de Itatinga, de sua antiga concorrente, a companhia Docas de Santos. Contudo, a solução definitiva viria anos mais tarde, com a construção da usina de Cubatão, num ambiente em que o monopólio da Light não era mais contestado, e em que a cidade de São Paulo havia assumido a posição de centro industrial e econômico do país.

Assim, de maneira geral, as duas primeiras décadas do século XX foram decisivas para a consolidação do setor de energia elétrica na cidade de São Paulo. A chegada da Light ao mercado paulista, num contexto de pouco regulamentação, permitiu que a empresa estrangeira avançasse de forma surpreendente pela capital, conquistando o monopólio de todos os serviços urbanos num período de uma década. O papel de Câmara Municipal, que inicialmente era de intermediário nos conflitos para aquisição das concessões dos serviços, foi tornando-se mais ativo na fiscalização da qualidade dos serviços. A década de 1920, foi portanto, o momento em que o discurso hegemônico de um estado ausente da prestação de serviços vai se transformando, possibilitando que anos mais tarde, um estado centralizador pudesse regular firmemente os serviços públicos.

\section{Referências Bibliográficas}

BARROS, Geraldo Mendes. Guilherme Guinle, 1882-1960. São Paulo: Agir Editora, 1982.

BEIGUELMAN, Giselle. \& FARIA, Nívia. A empresa política. História e energia. A chegada da Light. São Paulo: Eletropaulo, 1986.

BOLETIM HISTÓRICO 5. O monopólio contestado. São Paulo: Eletropaulo, 1986.

CARONE, Edgar e PERAZZO, Priscila. Em São Paulo, lutas contra o monopólio. A mobilização social no conflito Guinle x Light. Memória. No 7. São Paulo: Eletropaulo, 1990. 
HANSEN, Cláudia Regina S. de Oliveira. O poder da Companhia Brasileira de Energia Elétrica em Petrópolis (1909-1927). Niterói: dissertação de Mestrado - UFF, 2006.

KUGELMAS, Eduardo. A difícil hegemonia. São Paulo: tese de doutorado - USP, 1986.

LAMARÃO, Sérgio Tadeu de Niemeyer. A energia elétrica e o parque industrial carioca (1880-1920). Niterói: Tese de Doutorado - UFF, 1997.

McDOWALL, Duncan. The Light. Brazilian Traction, Light and Power Company Limited: 1899-1945. Toronto: University of Toronto Press, 1988.

MELLO, João Manuel Cardoso de. O capitalismo tardio. São Paulo:

Brasiliense, 1986.

MELLO, Zélia Maria Cardoso de. Metamorfoses da riqueza. São Paulo: 1845-1895. São Paulo: Hucitec, 1985.

MENDES, Dirce de Paula. Bondes ou luz? Eis a questão. Memória. No 13. São Paulo: Eletropaulo, 1991.

MENDES, Dirce, POLETI, Iraci e SOARES, Luiza. A formação do grupo Light. Memória. No 24. São Paulo: Eletropaulo, 1995.

PASCHKES, Maria Luísa N. de Almeida. Bondes, terrenos e especulação. História e Energia. A chegada da Light. São Paulo:

Eletropaulo, 1986.

PERISSINOTO, Renato. Classes dominantes e hegemonia na República Velha. Campinas: Unicamp, 1994.

PINTO, Paulo Alves. Aspectos da penetração imperialista no Brasil: The Brazilian Traction Light and Power. Revista Brasiliense (5), maio 1956.

PONTES, José Alfredo. O Brasil na visão da Light. Memória. No 16. São Paulo: Eletropaulo, 1992.

PONTES, José Alfredo. A Light e a imprensa. Memória. No 22. São Paulo: Eletropaulo, 1995.

SAES, Alexandre. Conflitos do capital: Light versus CBEE na formação do capitalismo brasileiro (1898-1927). Campinas: tese de doutorado UNICAMP, 2008.

SAES, Flávio. A grande empresa de serviços públicos na economia paulista. São Paulo: Hucitec, 1986.

SEGATTO, José Antônio. Relações e conflitos de trabalho na Light de São Paulo. In: SZMRECSÁNYI, Tamás \& MARANHÃO, Ricardo. História de empresas e desenvolvimento econômico. São Paulo: Hucitec, 2002. 
LUZ, LEIS E LIVRE-CONCORRÊNCIA:...

SIMÕES DE PAULA, Eurípedes. Contribuição Monográfica para o Estudo da Segunda Fundação de São Paulo. Revista de História. São Paulo: FFCL/USP, n. 17, 1958.

SILVA, Heloísa B. da. Batalhas pelo Monopólio. História e Energia. A chegada da Light. São Paulo: Departamento de Patrimônio Histórico, 1986.

SILVA, João Luiz Maximo da. As empresas de energia e o consumo doméstico de gás em São Paulo no início do século XX. História econômica e história de empresas, IX.2. São Paulo: Associação de Pesquisadores em História Econômica - ABPHE, 2006.

SILVA, Sérgio. Expansão cafeeira e origem da indústria no Brasil. São Paulo: Alfa-Ômega, 1976.

SOUZA, Edgar de. A história da Light. Os primeiros 50 anos. São Paulo: Eletropaulo, 1982.

\section{Fontes Impressas}

CASTRO Jr., Francisco de. O privilégio da Light and Power. Razões finais na ação movida por Guinle \& C. contra a Light and Power e a Municipalidade. Rio de Janeiro: Papelaria Americana, 1909.

CBEE. Rapport general sur les usines, l'organization, les concessions et les franchises de la Companhia Brazileira de Energia Electrica. Rio de Janeiro : Bureau de Londres, [s.d.].

GUINLE \& CO. La question de l'électricité dans Rio de Janeiro. La Compagnie Light \& Power contre la Compagnie Brésilienne d'Énergie Électrique et Guinle \& Cie. Rio de Janeiro: Guinle \& Cie., 1911. GUINLE, Eduardo. A Light e seus negócios da China. Jornal do Comércio, 14 de março de 1933.

Anais da Câmara Municipal de São Paulo e Anais do Senado do Estado de São Paulo (1900-1920).

Companhia Brasileira de Energia Elétrica. Diário Oficial da União (19091930).

SP LIGHT, The São Paulo Tramway, Light \& Power Company Limited, Annual Report, 1902-1920.

Jornais e Revistas: ${ }^{84}$ Jornal do Commercio de São Paulo, A Platéia, Correio Paulistano, O Estado de São Paulo, A Notícia, A Gazeta, Diário Popular e Revista Brazil Ferro-Carril. 
SAES, Alexandre Macchione. Light, laws and liberalism: conflicts in the São Paulo's electric light sector during the beninning of the 20th century. História, v.28, n.2, p.173-234, 2009.

\begin{abstract}
This paper discusses the introduction of electric power in the city of São Paulo during the beginning of the $20^{\text {th }}$ century. The Brazilian Republic Proclamation (1889) established the beginning of the public services companies' modernization, which through the enterprises fusion and the arrival of foreign capital allowed the electric power introduction in the main Brazilian cities. Two rival groups started a competition in the São Paulo's electric sector: the national enterprise Companhia Brasileira de Energia Elétrica (CBEE) - so called as Docas de Santos - and the Canadian company Light. The inexistence of a federal legislation to electric power services had transformed municipal decisions in deterministic guidelines for utility bids, making municipal lobbying a key instrument in utility concessions. Hence, this paper issues describe the electric power introduction in the city through the debates about the utilities' rules, analyzing the political or ideological criteria that build the São Paulo's laws for electricity sector.
\end{abstract}

Keywords: Electric power; São Paulo; Light, Docas de Santos.

\title{
NOTAS
}

${ }^{1}$ Esse era o ambiente de expansão do grande capital cafeeiro, capital oriundo das atividades agrário-exportadoras que se diversificou para as ferrovias, bancos e empresas de serviços públicos. Uma longa bibliográfica explora tal processo: Silva (1976), Mello (1985), Mello (1986), Saes (1986), Kugelmas (1886) e Perissinotto (1994).

${ }^{2}$ Para os conflitos entre as empresas no Rio de Janeiro: Lamarão (1997), Hansen (2006) e Saes (2008).

${ }^{3}$ Os jornais do período se referiam aos conflitos pelo mercado de eletricidade de São Paulo como entre a empresa canadense Light e a nacional Docas de Santos. Contudo, no setor de energia elétrica a empresa dos diretores da companhia Docas de Santos era chamada de 
LUZ, LEIS E LIVRE-CONCORRÊNCIA:...

Guinle \& Co. até o ano de 1909, quando foi formada a empresa Companhia Brasileira de Energia Elétrica (CBEE).

${ }^{4}$ Lei $\mathrm{n}^{\circ} 407$, de 21 de julho de 1899, artigo 12.

${ }^{5}$ Correio Paulistano, 10 de maio de 1899.

${ }^{6}$ Diário Popular, 29 de agosto de 1899.

${ }^{7}$ Segundo o artigo número 2 do contrato: "O privilégio concedido a 'The São Paulo Tramway, Light and Power Company' consiste no direito exclusivo pelo prazo de 40 anos, de transportar passageiros e cargas em tramways por tração elétrica (...) nas ruas, praças e vias públicas já servidas por linhas de tramways, ou aquelas que já são objeto de concessões já feitas...". Anexo II. Contrato de Unificação para o serviço de viação urbana - 17 de julho de 1901 (SILVA, 1986, p. 48-9).

${ }^{8}$ Diário Oficial do Estado de São Paulo, 8 de dezembro de 1901, p. 2.941.

${ }^{9}$ Guinle \& Co., representante da GE no Brasil, era uma das empresas que vendiam as tais lâmpadas novas e, em propaganda, comparavam: o custeio anual da lâmpada com fio de carvão é de 37\$200 réis, enquanto da lâmpada de fio metálico é de $15 \$ 200$ réis. O Estado de São Paulo, 23 de abril de 1910.

${ }^{10}$ Foi nesse cenário que a empresa passou a investir mais plenamente nos serviços de outros fins (isso é, basicamente fogões e aquecedores). Assim, o fornecimento de gás com "fins estranhos à iluminação", que começou a ser implementado em 1901 - para um fogão a gás no Palácio do Governo -, já em 1910 era igualado ao uso para iluminação pública e particular, resultado da expansão do uso do gás como combustível doméstico, alcançando os $89 \%$ do consumo total de gás na cidade de São Paulo em 1928 (SILVA, 2006, p.77).

${ }^{11}$ Commercio de São Paulo, 6 de agosto de 1910.

${ }^{12}$ A Platéia, 5 de novembro de 1906.

${ }^{13}$ Correio Paulistano, 19 de setembro de 1907.

14 Vale ressaltar o dado que, ainda em 1920, na indústria de transformação brasileira, a produção da energia nos próprios estabelecimentos ultrapassava os cinqüenta por cento. A produção de eletricidade via terceiros correspondia a $47,3 \%$; a energia produzida pelos próprios estabelecimentos era dividida entre: $36,2 \%$ vapor, $7,7 \%$ turbinas hidrelétricas, 5,3\% combustão interna, 2,7\% rodas de água e $0,8 \%$ outros (SAES, 1986, p.29).

${ }^{15}$ A unificação dos contratos se justificava pelo controle da São Paulo Light de todas as possíveis concessões de iluminação e distribuição de 
energia elétrica da cidade: Gualco e Souza, Água e Luz e São Paulo Gás Co.

${ }^{16}$ Anais da Câmara Municipal de São Paulo, 7 de junho de 1912.

${ }^{17}$ O Estado de São Paulo, 9 de junho de 1909.

18 BOLETIM HISTÓRICO 5. O monopólio contestado. São Paulo: Eletropaulo, 1986, p.5-7.

${ }^{19}$ A Gazeta, 17 de fevereiro de 1909.

${ }^{20}$ O Estado de São Paulo, 27 de fevereiro de 1909.

${ }^{21}$ O Estado de São Paulo, 8 de abril de 1911.

${ }^{22}$ A Notícia, 09 de outubro de 1907.

${ }^{23}$ Vale lembrar que o membro da diretoria da Light, Alfredo Maia, havia sido Ministro da Agricultura da União e, também, superintendente da ferrovia Sorocabana, cujo arrendamento acabou favorecendo Percival Farquhar, empresário norte-americano aliado do grupo Light no Rio de Janeiro e na Bahia.

${ }^{24}$ Mas, na verdade, não passavam de operações financeiras do grupo que escondiam a verdadeira rentabilidade da empresa. Conforme descrição de Eduardo Guinle: "O funcionamento faz-se de modo muito engenhoso, mas contrário ao interesse público. Os 'promotores', munidos dos contratos de concessão ou de opções, apresentam-se aos capitalistas 'sedentários' e mostram as garantias e o futuro do negócio. Obtêm, a juros baixos e prazos razoáveis, o dinheiro com que vão executar os compromissos assumidos. Começa o negócio a produzir e a renda inicial se destina ao pagamento dos juros e à amortização desse capital temporário. À proporção que amortizam esse capital, vão os 'promotores' emitindo ações ordinárias que, sem nenhuma entrada de dinheiro, passam a ter dividendo. Cresce a renda e o capital temporário é todo resgatado, fincando em seu lugar ações de um capital fictício, em mãos dos 'promotores' que desde então se tornam capitalistas. (É o caso dos 13 1 1/2 milhões de dólares iniciais da Light)." (GUINLE, 1933). E semelhante análise é feita por Paulo Alves Pinto (1956).

${ }^{25}$ O Estado de São Paulo, 20 de março de 1909.

${ }^{26}$ A Gazeta era um jornal que abertamente defendia a Light dentro dos meios de comunicação, sob a direção de Adolfo Campos de Araújo, conhecido por sua admiração pelo progresso material e pelos países industrializados. De certa forma, a Light era representante do desenvolvimento e das inovações realizadas no estrangeiro. Assim, desde o seu primeiro número, de 16 de maio de 1906, até a morte de Adolfo, em 1917, A Gazeta foi um grande meio de comunicação 
LUZ, LEIS E LIVRE-CONCORRÊNCIA:...

defensor da Light, porém, com sua venda para o grupo do jornalista Cásper Líbero (em 1917), terminava a fase lightiana do jornal (PONTES, 1995).

${ }^{27}$ A Platéia, 18 de junho de 1912.

${ }^{28}$ A Platéia, 11 de março de 1909.

${ }^{29}$ O Estado de São Paulo, 6 de março de 1909.

30 O Estado de São Paulo, 6 de março de 1909.

${ }^{31}$ O Estado de São Paulo, 8 de março de 1909.

32 O Estado de São Paulo, 13 de março de 1909. Segundo o despacho do Prefeito Antonio Prado, por meio da decisão de 25 de fevereiro de 1909, ficava decidido: "Aprovo a autorização demandada, conforme a Lei $n^{\circ} 407$, de 21 de Julho de 1899, estabelecendo o regime de livre-concorrência com relação aos serviços de transmissão e distribuição de energia elétrica e de iluminação elétrica desta cidade e de seus subúrbios, a condição que a presente concessão será subordinada a aprovação das plantas, áreas e projetos de todos os trabalhos que serão executados (...) no prazo máximo de quatro meses". (CBEE, [s.d.], p. 228).

${ }^{33}$ Em 1901, por meio do decreto federal $n^{\circ} 4.088$, de 22 de julho, a Docas de Santos era autorizada a realizar estudos para utilização de energia elétrica no rio Jurubatuba e seus afluentes. O governo federal, ao ser informado da impossibilidade de se produzir energia neste rio, liberou para o grupo a utilização dos "rios que os respectivos estudos demonstrassem convenientes à transformação de força elétrica motora nas oficinas dos serviços de Santos", por meio do decreto $n^{\circ} 4.235$, de 11 de novembro de 1901 (BARROS, 1982, p.24).

${ }^{34}$ Correio Paulistano, 17 de fevereiro de 1909.

${ }^{35}$ Autorização descrita nos relatórios da São Paulo Light. Annual Report, 1909, p. 49. O decreto $n^{\circ} 7.100$, de 3 de setembro de 1908, foi assinado por Afonso Pena, presidente da República, e Miguel Camon du Pin e Almeida, Ministro do MVOP, que permitia a construção das linhas de transmissão de Itapanhaú, na cidade de Santos, para São Paulo, da usina que seria construída naquele local (CBEE, [s.d.], p. 226).

${ }^{36}$ O Estado de São Paulo, 2 de março de 1909.

${ }^{37}$ O Estado de São Paulo, 6 de março de 1909.

${ }^{38}$ São Paulo Light, Annual Report, 1909, p.52.

${ }^{39}$ Anais da Câmara Municipal de São Paulo, 29 de abril de 1909.

${ }^{40}$ A Notícia, 2 de março de 1909.

${ }^{41}$ O Estado de São Paulo, 9 de julho de 1909.

${ }^{42}$ Lei $\mathrm{n}^{\circ} 1.210$ de 29 de abril de 190, interpretação da Lei nº 407 de 1899.

${ }^{43}$ Anais do Senado do Estado de São Paulo, 1909, p. 50.

${ }^{44}$ Resolução no 23 A. Anais do Senado do Estado de São Paulo, 20 de dezembro de 1909. 
${ }^{45}$ A Gazeta, 28 de abril de 1909.

${ }^{46}$ Diário Popular, 1 de maio de 1909.

${ }^{47}$ Anais da Câmara Municipal de São Paulo, 26 de junho de 1911.

48 Entre 1901 e 1912, a Usina de Parnaíba manteve um crescimento contínuo, com a implementação de geradores até alcançar a potência de $16.000 \mathrm{kw}$. Contudo, o crescimento do consumo vinha acompanhando de perto a expansão da produção, de maneira que, em caráter de urgência, foi colocada em operação a usina termelétrica de Paula Souza em 27 de setembro de 1912 (com mais 4.000 kw). Mas a solução decisiva para falta de energia durante a década de 1910 foi somente resolvida com a inauguração da Usina de Itupararanga, que quase triplicou a produção de energia em 1914 (SOUZA, 1982, p. 160).

49 Mas esse acordo, depois de mais de uma década, acabou se consolidando. Contudo, o contexto era diferente daquele de outrora: a Light já havia finalmente conquistado o privilégio de atendimento dos mercados de São Paulo e Rio de Janeiro e estendido seus prazos de concessão, enquanto a CBEE iniciava uma reformulação na empresa que culminaria com a venda de suas propriedades para a Amforp. É nesse sentido que o relatório de 1925 narra a realização do contrato com a São Paulo Light: "No correr do ano de 1925 fizemos um acordo com a São Paulo Tramway Light \& Power e a Companhia Docas de Santos para o fornecimento àquela empresa de energia gerada na Usina Itatinga. Para isso, cedemos à São Paulo Tramway a nossa concessão de Itapanhaú e a faixa de linha de transmissão entre o rio e São Paulo". Arquivo Nacional. Diário Oficial da União, 24 de abril de 1926, p. 8505.

${ }^{50}$ Brazil Ferro-Carril, n 23 , novembro de 1911, p. 8.

51 A empresa, que havia acabado de inaugurar uma pequena hidrelétrica em Salesópolis, apresentava os mesmos argumentos da Docas de Santos, isto é, que o sistema de concessões da cidade era de livre-concorrência, de maneira que outras empresas teriam permissão para assumir áreas ainda não atendidas dentro da cidade, e que a Light não poderia expandir seu tempo de concessão nos termos tratados. Contudo, o pedido que reaparece no início do ano de 1913 desapareceu das atas da Câmara nos anos seguintes. O grupo, que nos anos vinte figurava como segunda maior empresa nacional no Estado de São Paulo em potência instalada, atendendo a região de Moji das Cruzes, Caçapava e Pindamonhangaba, nos anos trinta seria 
LUZ, LEIS E LIVRE-CONCORRÊNCIA:...

concessionário da Light. Anais da Câmara Municipal de São Paulo, 22 de novembro de 1912 e 31 de janeiro de 1913.

${ }^{52}$ Assumia, então, a presidência do grupo Guilherme Guinle. Brazil Ferro Carril, n 27 , março de 1912.

${ }^{53}$ Anais da Câmara Municipal de São Paulo, 13 de março de 1912.

${ }^{54}$ O Estado de São Paulo, 3 de junho de 1912.

55 No projeto de ampliação da concessão, a Light se comprometia aumentar a contribuição à municipalidade para além dos 100:000\$000 anuais, mais $21 / 2$ por cento sobre a renda bruta dos serviços de bondes e força e luz. Anais da Câmara Municipal, 5 de maio de 1912.

${ }^{56}$ O Estado de São Paulo, 3 de junho de 1912.

${ }^{57}$ O Estado de São Paulo, 9 de julho de 1912.

${ }^{58}$ O Estado de São Paulo, 9 de julho de 1912.

${ }^{59}$ A Platéia, 13 de julho de 1912.

${ }^{60}$ Diferentemente do que alega Duncan McDowall no livro The Light (1988, p.173), Raymundo Duprat esteve intimamente alinhado com os interesses da Light. Já como prefeito da capital, Duprat emitiria parecer em 21 de agosto de 1911 autorizando a renovação da concessão da empresa canadense, parecer este que seria reafirmado em 1912 durante os debates na Câmara. Anais da Câmara Municipal, 21 de agosto de 1911.

${ }^{61}$ Anais da Câmara Municipal, 20 de setembro de 1912.

${ }^{62}$ Parecer n ${ }^{\circ} 54$ da Comissão de Finanças. Anais da Câmara Municipal, 7 de julho de 1912.

${ }^{63}$ Vale ressaltar que Carlos de Campos, aliado da Light desde a chegada da empresa canadense no Brasil, teve papel importante também na aprovação do projeto de construção da usina hidrelétrica de Cubatão, afinal, no período ele era tão somente o governador do estado de São Paulo (PONTES, 1992, p.55).

${ }^{64}$ Diário Popular, 26 de julho de 1912.

${ }^{65}$ Commercio de São Paulo, 22 de fevereiro de 1909.

${ }^{66}$ American Cold, "Secção Livre: A Light e Câmara". O Estado de São Paulo, 19 de janeiro de 1913.

${ }^{67}$ O Commercio de São Paulo, dias 10, 11, 12, 13 e 14 de julho de 1907.

${ }^{68}$ O Estado de São Paulo, 25 de junho de 1908.

69 Pai de Oswald de Andrade, José Oswald foi vereador nas legislaturas de 1899-1902, de 1902-1905 e 1908-1911, participando ativamente na defesa dos interesses da Light na capital paulista. 
${ }^{70}$ Correspondências trocadas entre os diretores da Light Walmsley e Alexander Mackenzie relatavam que: "essa tarde, Dr. José Oswald, vereador, ficou de encontrar o Dr. Maia e, como o segundo não estiva, Oswald pediu-me para contar-lhe que falando com o prefeito, Dr. Maia disse-lhe que poderíamos colocar um recurso dentro de 10 dias contados a partir do despacho do prefeito sobre a petição de Guinle e que a lei pode ser modificada mediante troca de favores" (BEIGUELMAN, e FARIA, 1986, p.37).

${ }^{71}$ Ofícios da Light and Power, Anais da Câmara Municipal São Paulo, 14 de agosto de 1911.

${ }^{72}$ A Platéia, 11 de março de 1909. (Grifo nosso).

${ }^{73}$ Anais da Câmara Municipal de São Paulo, 29 de novembro de 1912.

${ }^{74}$ Era também reunida nesta nova empresa a São Paulo Electric Co., originalmente denominada de Brazilian Steel and Smelting Co., sociedade anônima com sede em Toronto e formada pelos mesmos empresários da São Paulo Light, cuja concessão atendia os municípios de Sorocaba e São Roque, além de repassar energia para a São Paulo Light distribuir para São Paulo por meio da usina de Itupararanga.

75 O crescimento da receita de 1917 havia sido de 7,59\%, o de 1918, $10,89 \%$, o de 1919, 15,2\%, e, finalmente, o de 1920, incríveis 23\% (SP LIGHT, 1917-1920).

${ }^{76}$ Anais da Câmara Municipal de São Paulo, 13 de setembro de 1919.

${ }^{77}$ Anais da Câmara Municipal, 6 de junho de 1919.

${ }^{78}$ Anais da Câmara Municipal de São Paulo, 11 de outubro de 1919.

${ }^{79}$ Requerimento $n^{\circ} 397$ de 1919, Anais da Câmara Municipal de São Paulo, 11 de outubro de 1919.

${ }^{80}$ Anais da Câmara Municipal de São Paulo, 24 de março de 1920.

${ }^{81}$ Anais da Câmara Municipal de São Paulo, 7 de fevereiro de 1920.

${ }^{82}$ Para Anhaia Mello: "Nós temos, porém, um contrato que regula o assunto: precisamos dar existência real a um certo número de cláusulas desse contrato, que não têm sido observadas. Isso tudo, quero crer, se resume numa só palavra: fiscalização". Anais da Câmara Municipal de São Paulo, 24 de março de 1920.

${ }^{83}$ SOUZA, 1982, p.86-7.

${ }^{84}$ Jornais e revistas compulsados incompletamente entre 1900-1920.

Artigo recebido em 04/2009. Aprovado em 07/2009. 